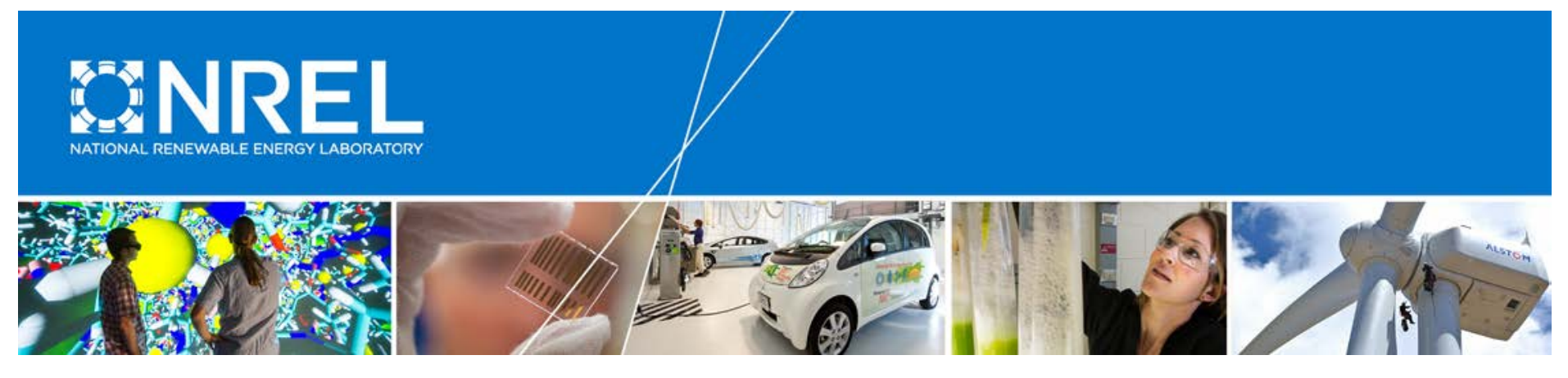

\title{
The Price-Concentration Relationship in Early Residential Solar Third-Party Markets
}

Jacquelyn Pless

Oxford Martin Programme on Integrating Renewable Energy at the Oxford Martin School, Institute for New Economic Thinking, University of Oxford

Ria Langheim, Christina Machak, and Henar Hellow

Center for Sustainable Energy

Ben Sigrin

National Renewable Energy Laboratory

NREL is a national laboratory of the U.S. Department of Energy Office of Energy Efficiency \& Renewable Energy Operated by the Alliance for Sustainable Energy, LLC

This report is available at no cost from the National Renewable Energy Laboratory (NREL) at www.nrel.gov/publications.

Technical Report

NREL/TP-6A20-66784

January 2017

Contract No. DE-AC36-08G028308 


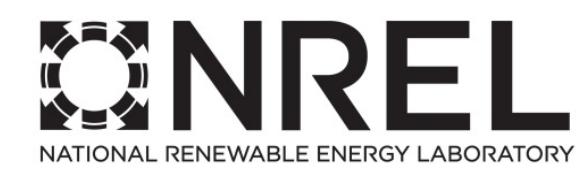

\section{The Price-Concentration Relationship in Early Residential Solar Third-Party Markets}

Jacquelyn Pless

Oxford Martin Programme on Integrating Renewable Energy at the Oxford Martin School, Institute for New Economic Thinking, University of Oxford

Ria Langheim, Christina Machak, and Henar Hellow

Center for Sustainable Energy

Ben Sigrin

National Renewable Energy Laboratory

Prepared under Task No. SM13.SB01

NREL is a national laboratory of the U.S. Department of Energy Office of Energy Efficiency \& Renewable Energy Operated by the Alliance for Sustainable Energy, LLC

This report is available at no cost from the National Renewable Energy Laboratory (NREL) at www.nrel.gov/publications.

National Renewable Energy Laboratory 15013 Denver West Parkway Golden, CO 80401

303-275-3000 • www.nrel.gov
Technical Report

NREL/TP-6A20-66784

January 2017

Contract No. DE-AC36-08G028308 


\section{NOTICE}

This report was prepared as an account of work sponsored by an agency of the United States government. Neither the United States government nor any agency thereof, nor any of their employees, makes any warranty, express or implied, or assumes any legal liability or responsibility for the accuracy, completeness, or usefulness of any information, apparatus, product, or process disclosed, or represents that its use would not infringe privately owned rights. Reference herein to any specific commercial product, process, or service by trade name, trademark, manufacturer, or otherwise does not necessarily constitute or imply its endorsement, recommendation, or favoring by the United States government or any agency thereof. The views and opinions of authors expressed herein do not necessarily state or reflect those of the United States government or any agency thereof.

This report is available at no cost from the National Renewable Energy Laboratory (NREL) at www.nrel.gov/publications.

Available electronically at SciTech Connect http:/www.osti.gov/scitech

Available for a processing fee to U.S. Department of Energy and its contractors, in paper, from:

U.S. Department of Energy

Office of Scientific and Technical Information

P.O. Box 62

Oak Ridge, TN 37831-0062

OSTI http://www.osti.gov

Phone: 865.576.8401

Fax: 865.576.5728

Email: reports@osti.gov

Available for sale to the public, in paper, from:

U.S. Department of Commerce

National Technical Information Service

5301 Shawnee Road

Alexandria, VA 22312

NTIS http://www.ntis.gov

Phone: 800.553 .6847 or 703.605 .6000

Fax: 703.605.6900

Email: orders@ntis.gov 


\section{Acknowledgments}

The U.S. Department of Energy Solar Energy Technologies Office under the Solar Energy Evolution and Diffusion Studies (SEEDS) program funded this project. We thank Ben Airth, David Bielen, Harrison Fell, Scott Gossett, Karin Haas, Kiran Lakkaraju, David Lehrer, Galen Maclaurin, Katrina Morton, Amy Nguyen-Chung, Unni Pillai, Billy Roberts, Tim Treadwell, and Eugene Vorobeychik for input and assistance on this project. We also thank the California Public Utility Commission (CPUC) for providing access to the data used in this study under a nondisclosure agreement. Opinions represented in this article are the authors' own and do not reflect the view of the U.S. Department of Energy or the U.S. Government. This work was supported by the U.S. Department of Energy under Contract No. DE-AC36-08GO28308 with the National Renewable Energy Laboratory. 


\section{List of Acronyms and Abbreviations}

ARRA

CPUC

CSE

CSI

CSS

DOE

ERP

FE

HHI

IOU

ITC

LP

MACRS

NPC

NREL

SDG\&E

SGIP

TPO
American Recovery and Reinvestment Act of 2009

California Public Utility Commission

Center for Sustainable Energy

California Solar Initiative

California Solar Statistics

U.S. Department of Energy

Emerging Renewables Program

Fixed Effects

Herfindahl-Hirschman Index

investor-owned utility

Investment Tax Credit

low-priced

Modified Accelerated Cost Recovery System

net present cost

National Renewable Energy Laboratory

San Diego Gas and Electric

Self-Generation Incentive Program

third-party ownership 


\section{Executive Summary}

The market for residential solar photovoltaic (PV) systems in the United States has experienced tremendous growth over the past decade, with installed capacity more than doubling between 2014 and 2016 alone (SEIA 2016). As the residential PV market continues to grow, it prompts new questions about the nature of competition between solar installers and how this competition, or lack thereof, affects the prices consumers pay. It is often assumed that more competition leads to lower prices, but this is not universally true. For example, some studies have shown that factors such as brand loyalty could lead to a negative relationship between concentration and price in imperfectly competitive markets (Borenstein 1985; Holmes 1989). As such, the relationship between prices and market concentration is an open empirical question because theory could predict either a positive or negative relationship.

Determining a relationship between prices and market concentration is challenging for several reasons. Most significantly, prices and market structure are simultaneously determined by each other - the amount of competition a seller faces influences the price they can command, while prices determine a seller's market share. Previous studies have examined recent PV pricing trends over time and between markets (Davidson, Steinberg, and Margolis 2015; Davidson and Margolis 2015; Nemet et al. 2016; Gillingham et al. 2014; Barbose and Darghouth 2015). While these studies of solar PV pricing are able to determine correlations between prices and market factors, they have not proven causation. This study fills that gap by focusing on identifying the causal relationship between market structure and the prices paid by consumers.

We use a unique data set on third-party owned (TPO) contract terms for the residential solar PV market in the San Diego Gas \& Electricity service territory to better understand this relationship. We found that firms charged higher prices in more competitive markets in our sample. The finding is robust across multiple definitions of firm concentration. 
Table ES-1. Regression Estimates of the Effect of HHI (Herfindahl-Hirschman Index), a Measure of Market Concentration, on Mean System Price

The results demonstrate a negative relationship between prices and $\mathrm{HHI}$.

\begin{tabular}{lccccccc}
\hline & $\mathbf{( 1 )}$ & $\mathbf{( 2 )}$ & $\mathbf{( 3 )}$ & $\mathbf{( 4 )}$ & $\mathbf{( 5 )}$ & $\mathbf{( 6 )}$ & $\mathbf{( 7 )}$ \\
\hline $\mathrm{HHI}$ & 0.006 & -0.261 & $-0.508^{*}$ & $-0.710^{* *}$ & $-0.669^{* *}$ & $-0.899^{* *}$ & $-1.062^{* *}$ \\
$($ Total) & $(0.404)$ & $(0.294)$ & $(0.288)$ & $(0.285)$ & $(0.299)$ & $(0.359)$ & $(0.495)$ \\
\hline Module Model FE & & $\mathrm{x}$ & $\mathrm{x}$ & $\mathrm{x}$ & $\mathrm{x}$ & $\mathrm{x}$ & $\mathrm{x}$ \\
Installer FE & & & $\mathrm{x}$ & $\mathrm{x}$ & $\mathrm{x}$ & $\mathrm{x}$ & $\mathrm{x}$ \\
System Characteristics & & & & $\mathrm{x}$ & $\mathrm{x}$ & $\mathrm{x}$ & $\mathrm{x}$ \\
House Characteristics & & & & & $\mathrm{x}$ & $\mathrm{x}$ & $\mathrm{x}$ \\
Demographic Controls & & & & & & $\mathrm{x}$ & $\mathrm{x}$ \\
Other Controls & & & & & & & $\mathrm{x}$ \\
Year ${ }^{*}$ Quarter FE & $\mathrm{x}$ & $\mathrm{x}$ & $\mathrm{x}$ & $\mathrm{x}$ & $\mathrm{x}$ & $\mathrm{x}$ & $\mathrm{x}$ \\
No. of Observations & 581 & 581 & 581 & 581 & 581 & 581 & 581 \\
\hline
\end{tabular}

Note: Installer Fixed Effects (FEs) are dummies for contractors that hold $>5 \%$ of market share in our sample. System characteristics include estimated Y1 solar output, a dummy if the system has more than 1 inverter, California Solar Initiative (CSI) rating, CSI rating squared, and CSI rebate adjusted for Modified Accelerated Cost Recovery System (MACRS) and the Investment Tax Credit (ITC). House characteristics include square footage, number of bathrooms, number of bedrooms, and built year. Demographic controls include median income, percentage of the population with a bachelor's degree, and median house value. Other controls include a dummy equal to one if the installer is vertically integrated, a dummy for the American Recovery and Reinvestment Act of 2009 (ARRA) (BuyAmerican), cumulative number of installations within a tract at the time of adoption, installer experience with TPOs, housing density by tract, and a dummy for systems that are coastal. Systems over $10 \mathrm{~kW}$ were omitted as well as systems with net present costs (NPCs) greater than $\$ 20 / \mathrm{kW}$ or less than $\$ 0.5 / \mathrm{kW}$. A $10 \%$ nominal discount rate is assumed for the NPC calculations. Asterisks denote ${ }^{*} p<0.10,{ }^{* *} p<0.05,{ }^{* *} p<0.01$. Standard errors clustered by census tract.

There are at least two potential explanations for our findings. First, firms could be conducting entry deterrence strategies. It is possible that firms are acting in a non-competitive way and setting prices lower than they would otherwise. Setting low prices that are below potential competitors' marginal costs could deter entrants and ensure a larger market share. Second, there could be a group of dominant firms (with a competitive fringe), and the dominant firms may occasionally engage in price wars. If this is true, prices should be lower in more concentrated markets during the price wars (Salinger 1990).

As the rooftop PV market continues to grow, market structure will remain a relevant policy issue in consideration of the potential for rooftop solar to contribute to decarbonization efforts or other policy objectives. This paper adds to the understanding of supply-side factors in scaling up solar markets in the residential sector. Generally, solar markets have become more competitive over the same time period that solar technology costs decreased. While solar system hard costs have come down, our research suggests that total costs are more nuanced in early solar system TPO markets. Policymakers can consider these findings when designing markets and use data to make informed decisions. 


\section{Table of Contents}

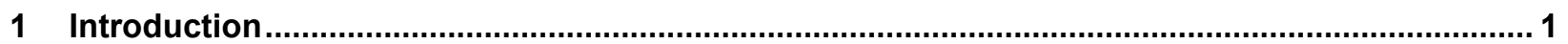

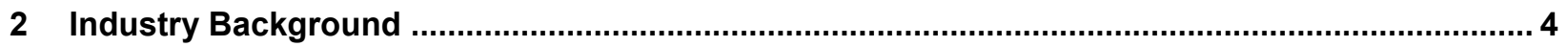

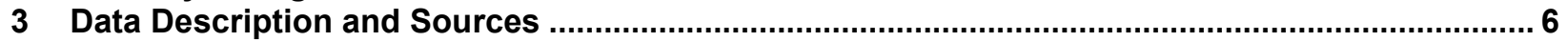

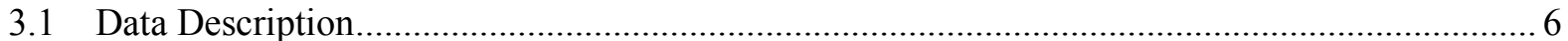

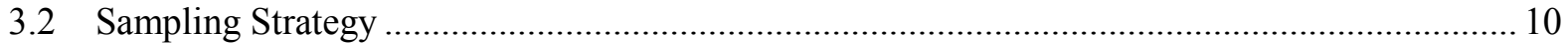

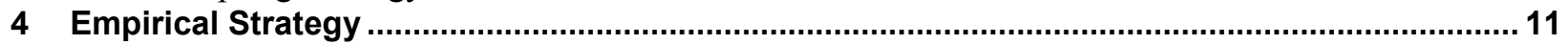

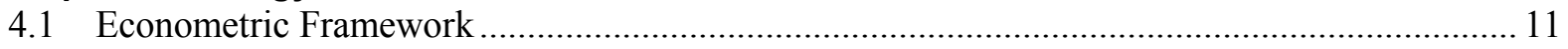

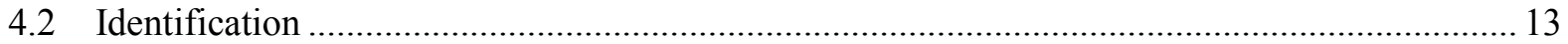

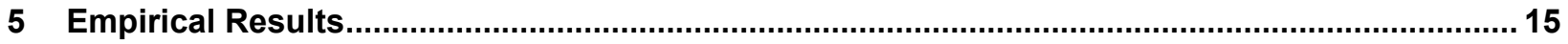

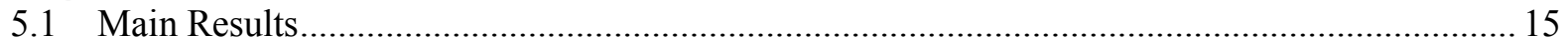

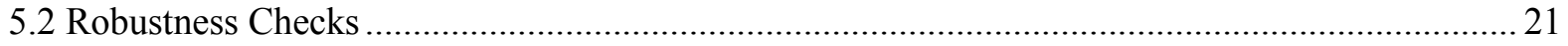

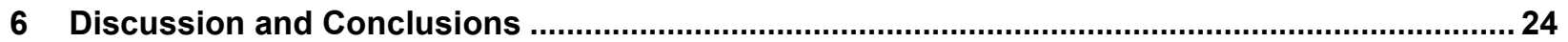

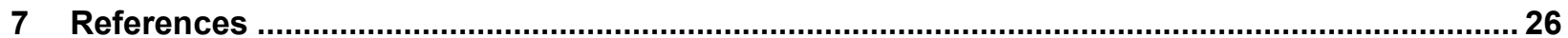

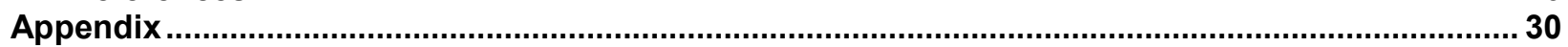




\section{List of Figures}

Figure 1. TPO market entrants and installation volume in the SDG\&E territory over time....................... 5

Figure 2. TPO market share as of Q1 2013 of top five installing solar companies .................................. 5

Figure A-1. Annual trends in contract net present cost (\$/W), HHI score, and number of installers active

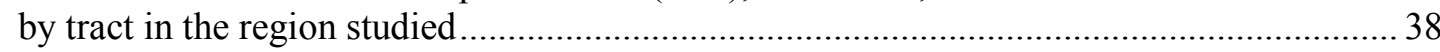

\section{List of Tables}

Table ES-1. Regression Estimates of the Effect of HHI (Herfindahl-Hirschman Index), a Measure of Market Concentration, on Mean System Price................................................................... vi

Table 1. Description of Constructed 'Market Structure' Measures ........................................................... 8

Table 2. Sample Summary Statistics of Market Concentration and System Price Variables .................... 10

Table 3. Main Instrumental Variable Regression Estimates of the Effect of HHI (Using all Installers in

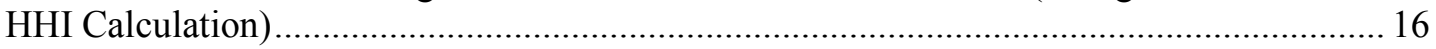

Table 4. Main Instrumental Variable Regression Estimates of the Effect of HHI (TPO Installers Only in

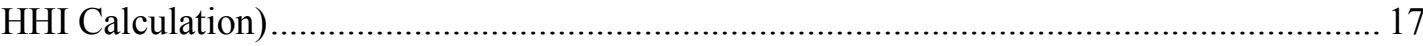

Table 5. Results for IV in First Stage Regressions ............................................................................. 18

Table 6. Main Instrumental Variable Regression Estimates of the Effect of Monopoly on Price, Monopoly $=1$ if $\mathrm{HHI}($ Total $)>0.25$.

Table 7. Main Instrumental Variable Regression Estimates of the Effect of Monopoly on Price, Monopoly

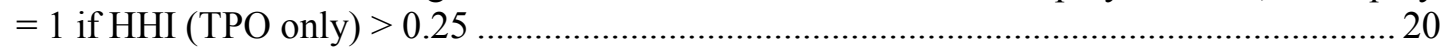

Table 8. Comparing Instrumental Variable (IV) Regression Results to Non-IV Results for HHI Measures

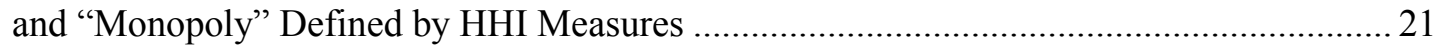

Table 9. Adding Disposable Income and Housing Growth Controls...................................................... 22

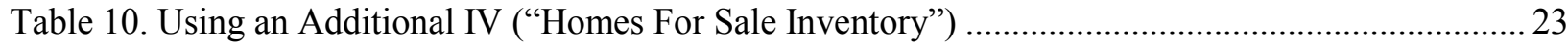

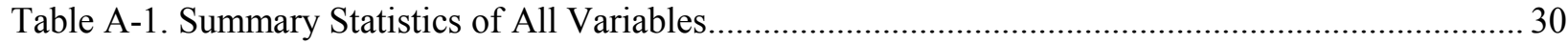

Table A-2. Main Instrumental Variable Regression Estimates of the Effect of Number of Installers (All

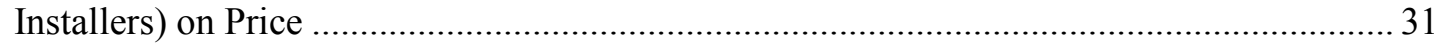

Table A-3. Main Instrumental Variable Regression Estimates of the Effect of Number of Installers

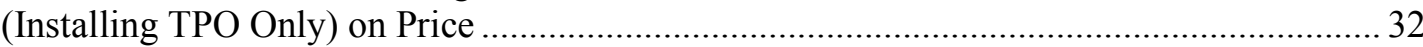

Table A-4. Main Instrumental Variable Regression Estimates of the Effect of "Monopoly Based on \# of Installations" on Price

Table A-5. Main Instrumental Variable Regression Estimates of the Effect of "Monopoly Based on \# of

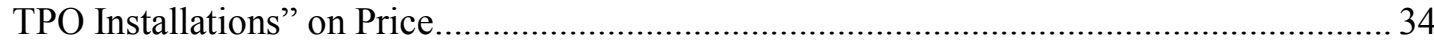

Table A-6. Estimates for Entire Set of Controls for Each Concentration Measure ….............................. 35

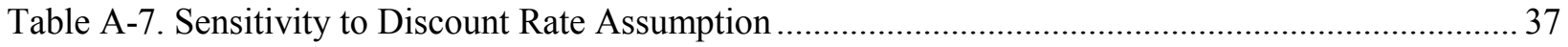




\section{Introduction}

The market for residential solar photovoltaic (PV) systems in the United States has experienced tremendous growth over the past decade, with installed capacity more than doubling between 2014 and 2016 alone (SEIA 2016). Several factors contributed to this growth, such as declining capital costs, government incentives, and increased consumer awareness of a new technology. Furthermore, new business models such as third-party ownership (TPO) have played a key role in increasing access to financing. Under typical TPO contracts, consumers can realize benefits of installing solar (i.e., energy bill savings) but also avoid taking on debt (Drury et al. 2012; Rai and Sigrin 2013; Davidson, Steinberg, and Margolis 2015; Shih and Chou 2011). TPO is now the dominant form of solar contracts in most U.S. markets.

Residential PV market growth prompts new questions about the nature of competition between solar installers and how this competition, or lack thereof, affects the prices consumers pay. Standard economic theory predicts that seller concentration is an important determinant of price in well-defined markets (Weiss 1989). It is often assumed that more competition leads to lower prices, but this is not universally true. For example, some studies have shown that factors such as brand loyalty could lead to a negative relationship between concentration and price in imperfectly competitive markets (Borenstein 1985; Holmes 1989). As such, the relationship between prices and market concentration is an open empirical question because theory could predict either a positive or negative relationship.

Determining a relationship between prices and market concentration is challenging for several reasons. Most significantly, prices and market structure are simultaneously determined by each other - the amount of competition a seller faces influences the price they can command and prices determine a seller's market share. There are two types of endogeneity bias. First, there is simultaneity bias - how well a firm performs affects their position among competitors. Second, measuring concentration as a function of firm revenue (price) alone necessarily introduces error because other factors affect firm revenue (Evans, Froeb, and Werden 1993). In the context of the residential solar market, even accurately determining the prices consumers paid is challenging because of the well-known biases in publicly reported data sets (Barbose and Darghouth 2015). As such, some prior studies of price-concentration in the economics literature may include endogeneity bias.

Previous studies have examined recent PV pricing trends over time and between markets (Davidson, Steinberg, and Margolis 2015; Davidson and Margolis 2015; Nemet et al. 2016; Gillingham et al. 2014; Barbose and Darghouth 2015). While these studies of solar PV pricing determine correlations between prices and market factors, proving causation is more difficult due to the lack of reliable and consistent data capturing the contract terms agreed upon between the seller and the solar adopter. This study fills that gap by focusing on identifying the causal relationship between market structure and the prices paid by consumers. There are two primary analyses to date that robustly explore the determinants of solar PV pricing. Gillingham et al. (2014) examine the relative importance of market structure, state and federal policies, and other factors on equilibrium solar PV system prices in the United States using data of roughly 100,000 residential and small commercial installations. The authors show that PV system prices differ based on market competition influences; higher installer densities but also higher market share are correlated with lower prices. However, Gillingham et al. (2014) frame the study on the basis 
of reported costs and do not explore the prices faced by individual TPO consumers in detail. Furthermore, the endogeneity of market structure is not addressed and thus the regression coefficient estimates for market structure could be biased.

The second main study of solar PV pricing in the literature is Nemet et al. (2016), which examines predictors of what the authors define as "low-priced" solar PV systems. This study is based on a similar data set as used in Gillingham et al. (2014). In this paper, however, the dependent variable is binary ( 1 if low-priced and 0 if non-low-priced), and the authors define low-priced (LP) in four ways for robustness purposes. The findings of this research suggest substantial differences between LP and non-LP systems in measures such as competition, firm characteristics, market characteristics, demographics, policies, costs, and system characteristics. However, Nemet et al. do not study the TPO prices faced by consumers as measured by contract terms and the endogeneity of market structure is not addressed, which could bias the results if attempting to identify a causal relationship between market structure and price.

We contribute to the literature by addressing two missing pieces in existing studies. First, we study TPO system pricing as measured by the contract terms agreed upon between the consumer and the third party. Our evaluation of proprietary contracts obtained through a non-disclosure agreement allows us to overcome the barrier of TPO pricing data availability. The analysis focuses on the residential solar PV market in the San Diego Gas \& Electric (SDG\&E) service territory, which includes San Diego County and parts of Orange County in California. The San Diego region was chosen because it is one of the more established residential PV markets in the United States, allowing us to understand how competition has evolved over several years (20072013). Second, while previous studies reveal interesting insights about the correlations between market structure, technology, and policy with system prices, we show that that there is a bias associated with ignoring the endogeneity of market structure. We use an instrumental variables (IV) approach in an attempt to remove this bias.

Our results suggest that firms have historically charged higher prices in more competitive markets, though we cannot confirm that these findings generalize to other regions or future markets, particularly as solar adoption increases. The results run counter to the common assumption that competition places downward pressure on prices, though we note several plausible explanations in Section 5 that are consistent with modern industrial organization theory. The findings are robust across a number of specifications and across eight measures of market structure. However, claiming to have identified a causal effect of competition on prices assumes that the IVs are valid. As such, although we find a bias to exist when the endogeneity of market structure is ignored, interpreting causality from our findings should be taken with caution.

As the rooftop PV market continues to grow, market structure will remain a relevant policy issue in consideration of the potential for rooftop solar to contribute to decarbonization efforts or other policy objectives. Our findings suggest that there is a negative relationship between market concentration and solar system pricing in early TPO markets; however, this could change as the structure of residential solar markets continues to evolve. 
The remaining of this paper is organized as follows. Section 2 provides background on the thirdparty solar PV market. In Section 3, we describe our data sources and sampling strategy, and we detail our econometric framework and identification strategy in Section 4. Finally, we present our empirical results in Section 5 and conclude in Section 6. 


\section{Industry Background}

The TPO solar market presents a unique setting to study the relationship between competition and pricing. The market is young, experienced a rapid growth, and has an increasing base of solar companies competing for customers. Among the myriad of solar companies, a few firms have gained considerable market share. This section contextualizes our empirical study by providing industry background on TPO arrangements, market growth, and the business landscape in California.

In a TPO arrangement, a third-party financier secures investor capital and tax equity to purchase PV systems on behalf of residential homeowners, providing a financed solution with no or low upfront cost to the homeowner. Under a TPO contract, the PV system host typically makes payments to the third-party owner of the system. Third-party financing of solar energy primarily occurs through two models: power purchase agreements (PPAs) and solar leases. ${ }^{1}$ Under these TPO models, the TPO financier-not the residential homeowner-receives all rebates, tax credits, and depreciation benefits. The TPO provider in turn offers a warranty for the system and provides some degree of system monitoring and operations and maintenance over the typical 20year lease term. ${ }^{2}$ At the end of the term, homeowners have three options: renew the lease, purchase the system at fair market value/set residual price, or have the system removed at no cost; however, the availability of each of these options varies.

The TPO model for solar, or solar as a service, was first introduced in the residential California market in 2007 . By 2012 , over $70 \%$ of new systems in the state were installed via TPO (CSI 2016). The current TPO business landscape is diverse, consisting of companies with varying sizes and structures. The residential TPO market in California quickly gained traction largely due to one main firm that offers vertically integrated TPO service solutions (Solar City). A vertically integrated TPO firm owns all the major parts of the solar business, including capital (TPO financing services), sales, installation, and after-sales service and maintenance. The majority of TPO arrangements deploy a non-integrated business model in which solar installers/developers pursue sales and system design, provide equipment, and install the system while partnering with TPO financiers who provide the financing service and hold responsibility for after-sales service and maintenance. Over time, a series of mergers took place in the TPO solar industry between TPO financiers and installer companies (e.g., Sunrun and REC Solar in 2014), which led to an increased number of vertically integrated firms.

The TPO industry has seen a significant number of market entrants over time including solar financiers, new solar developers, and solar developers/installers adding TPO options to their existing host-owned system installation businesses (Kann 2013). In the SDG\&E territory, the number of solar companies offering TPO systems in the residential market grew between 2007 and 2012 (Figure 1).

\footnotetext{
${ }^{1}$ Under a Lease agreement, solar customers typically pay fixed monthly payments over the period of the lease term. Under a PPA agreement, solar customers pay a fixed price per kilowatt-hour produced by the solar system.

${ }^{2}$ While 20 years is most common, lease terms in our sample range from 7 to 25 years.
} 


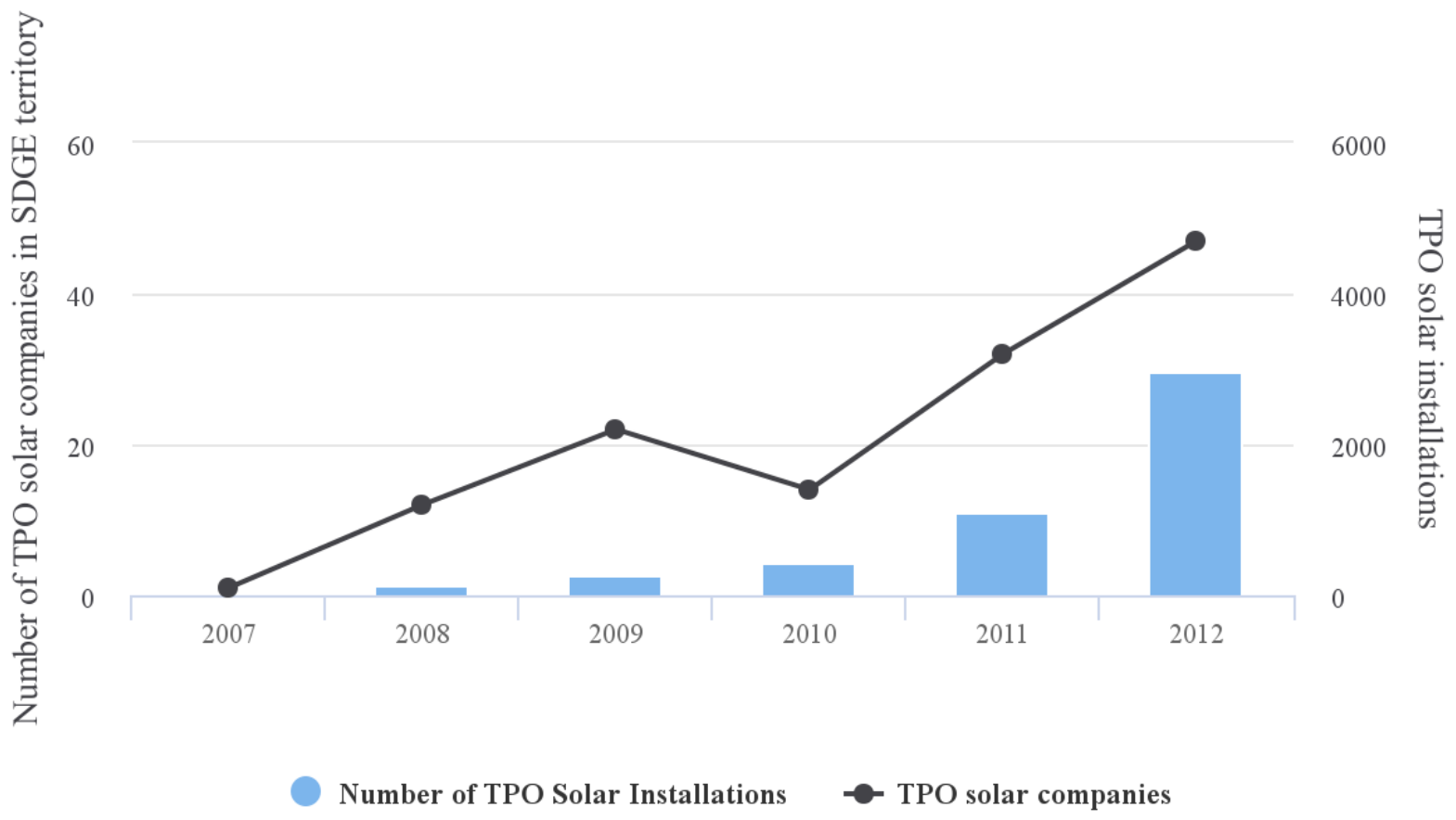

Figure 1. TPO market entrants and installation volume in the SDG\&E territory over time

This chart includes vertically and non-vertically integrated contractor companies in the general residential market. Data source: Created by authors using California Solar Initiative data.

While there are a large number of companies offering TPO systems in the residential sector, the market in the SDG\&E territory is dominated by a few firms. By the end of the first quarter of 2013 , the top five companies (by volume) held over $50 \%$ of the TPO market in the territory (Figure 2).

American Solar Direct: $\mathbf{5 . 5 \%}$

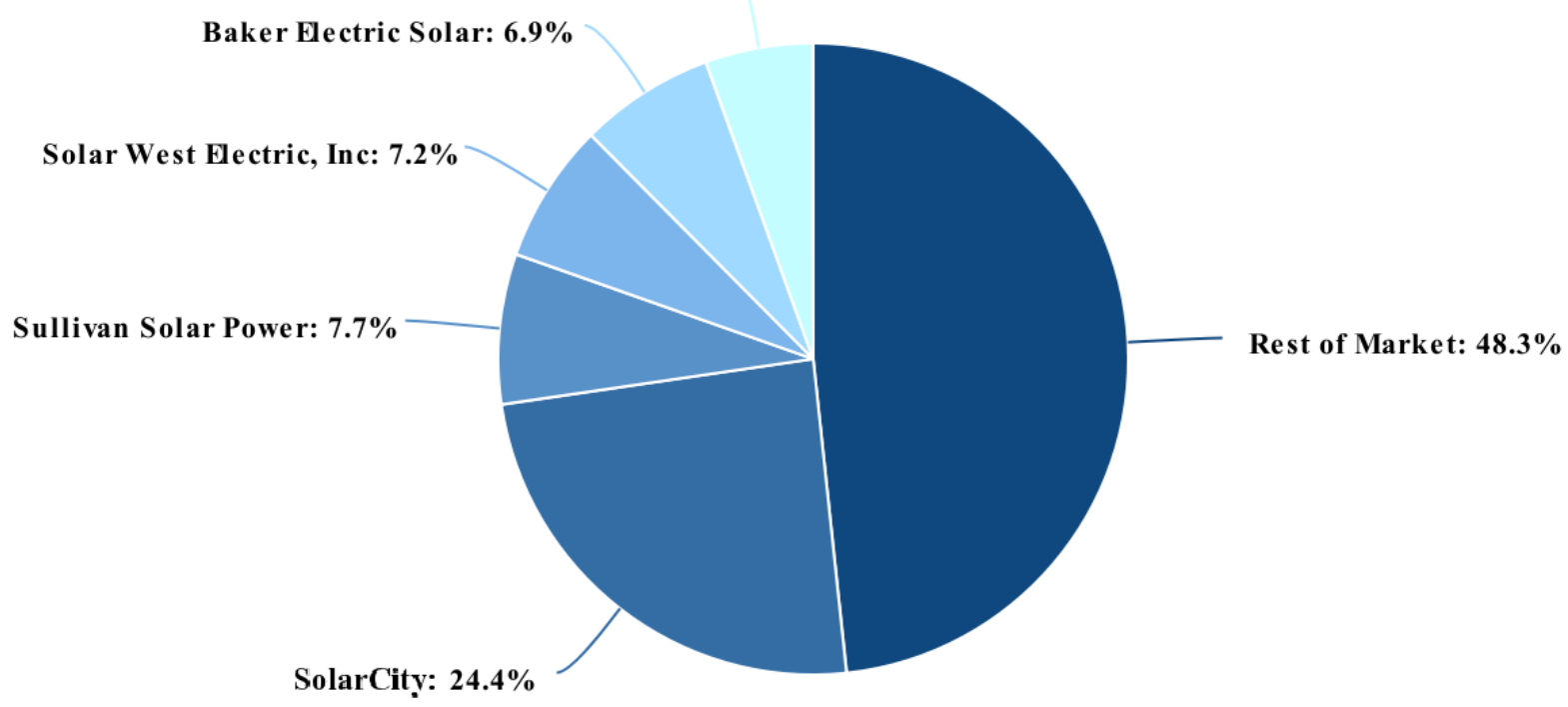

Figure 2. TPO market share as of Q1 2013 of top five installing solar companies

Data source: Created by authors using California Solar Initiative data. 


\section{Data Description and Sources}

We developed a unique database that combines numerous public and proprietary data sets that allowed us to match solar PV system-level data to TPO contract prices and to construct various control variables. This section describes the data that we compiled, our sampling strategy, and the construction of variables used throughout the empirical analysis, which is described in Section 4.

\subsection{Data Description}

Our empirical analysis focuses on residential solar PV installations in the SDG\&E territory in San Diego County and Orange County, California. We include only observations from the SDG\&E territory due to the availability of TPO contracts in that territory (administered by the Center for Sustainable Energy).

To obtain the population of residential solar systems in the SDG\&E utility territory, we combine address-level residential solar system data collected under the Emerging Renewables Program (ERP) and the California Solar Initiative (CSI) (CEC 2011). The first program provided rebates for small-scale residential renewable energy systems in the investor-owned utility (IOU) territories in California between 1998 and 2006. In 2007, the CSI was launched to incentivize the installation of solar for existing homes and existing or new commercial, agricultural, government, and nonprofit buildings.

We end our sample at the end of Q1 2013. The CSI incentive levels were designed to automatically step down over the duration of the program based on the cumulative capacity of solar installed within each IOU. In the second quarter of 2013, the incentive for the residential sector had reached very low levels, which resulted in some homeowners opting to install systems without incentives. Therefore, we end our sample at the end of Q1 2013 to ensure our data comprehensively represent the solar market in the SDG\&E territory.

We also include only systems listed as small residential in the general market, so systems that were installed in the affordable housing segment and those installed as part of new construction are dropped. To derive our cutoff date (Q1 2013) and stratify our sample across years, we utilize the interconnection date (proxy for installation date) of the solar systems obtained from the NEM Interconnection data set. ${ }^{3}$ The final data set includes 17,684 (4,121 ERP and 13,563 CSI) systems installed by the end of Q1 2013, 4,725 of which are TPOs.

The first set of variables that is critical to construct for our study include variables that capture "market structure,", or the competitiveness and/or concentration of solar installers within a market. The choice of an appropriate measure of market structure for our empirical analysis is not trivial because of the lack of theory on which measure is appropriate when the type of pricesetting behavior is unknown.

\footnotetext{
${ }^{3}$ We merged Solar Net Energy Metering Interconnection data set to the CSI data to obtain interconnection dates, which also provided more information about whether applicants that applied for an incentive installed the system. Furthermore, we excluded incentives for system additions in our sample.
} 
Therefore, we construct and employ eight different market structure measures for robustness purposes. Broadly, these fall within three basic categories: the Herfindahl-Hirschman Index $(\mathrm{HHI})^{4}$ (ranging between 0 and 1), number of installers, and "monopoly" (a binary indicator). A higher $\mathrm{HHI}$ indicates that a market is more concentrated (there are fewer installers in the market), so that an HHI equal to exactly one reflects a pure monopoly, whereas an HHI close to 0 represents a more competitive market. Furthermore, we create two separate "monopoly" variables. The first is equal to one if the number of installers is equal to one (and zero otherwise) and the other is equal to one if the HHI is above 0.25 , following the U.S. Department of Justice's Horizontal Merger Guidelines. ${ }^{5}$

Each market structure variable is measured by census tract (what we define as a "market") for unique installers that sold at least one system within the market in the period. Period is defined as the quarter-year of the incentive application date and the two preceding quarters.

This gives us four different measures of market structure (HHI, number of installers, and monopoly defined in two ways). We extend this further by creating two variables for each measure: one that considers all installers in the market (offering both TPO installation options as well as host-owned or purchased systems) and one that considers only installers using TPO. This gives us a total of eight market structure measures, which are summarized in Table 1.

\footnotetext{
${ }^{4}$ The Herfindahl-Hirschman Index (HHI) presents a measure of market concentration of firms in an industry based on their individual market shares. The HHI is calculated by squaring the market share for each firm and then summing the squares. The highest HHI value $(10,000)$ depicts a monopolistic market scenario, while values below 1,000 are deemed unconcentrated (competitive) markets. In our analysis, the HHI values are shown as an index between 0 and 1.

${ }^{5}$ These guidelines can be accessed here: https://www.justice.gov/atr/horizontal-merger-guidelines-08192010.
} 
Table 1. Description of Constructed 'Market Structure' Measures

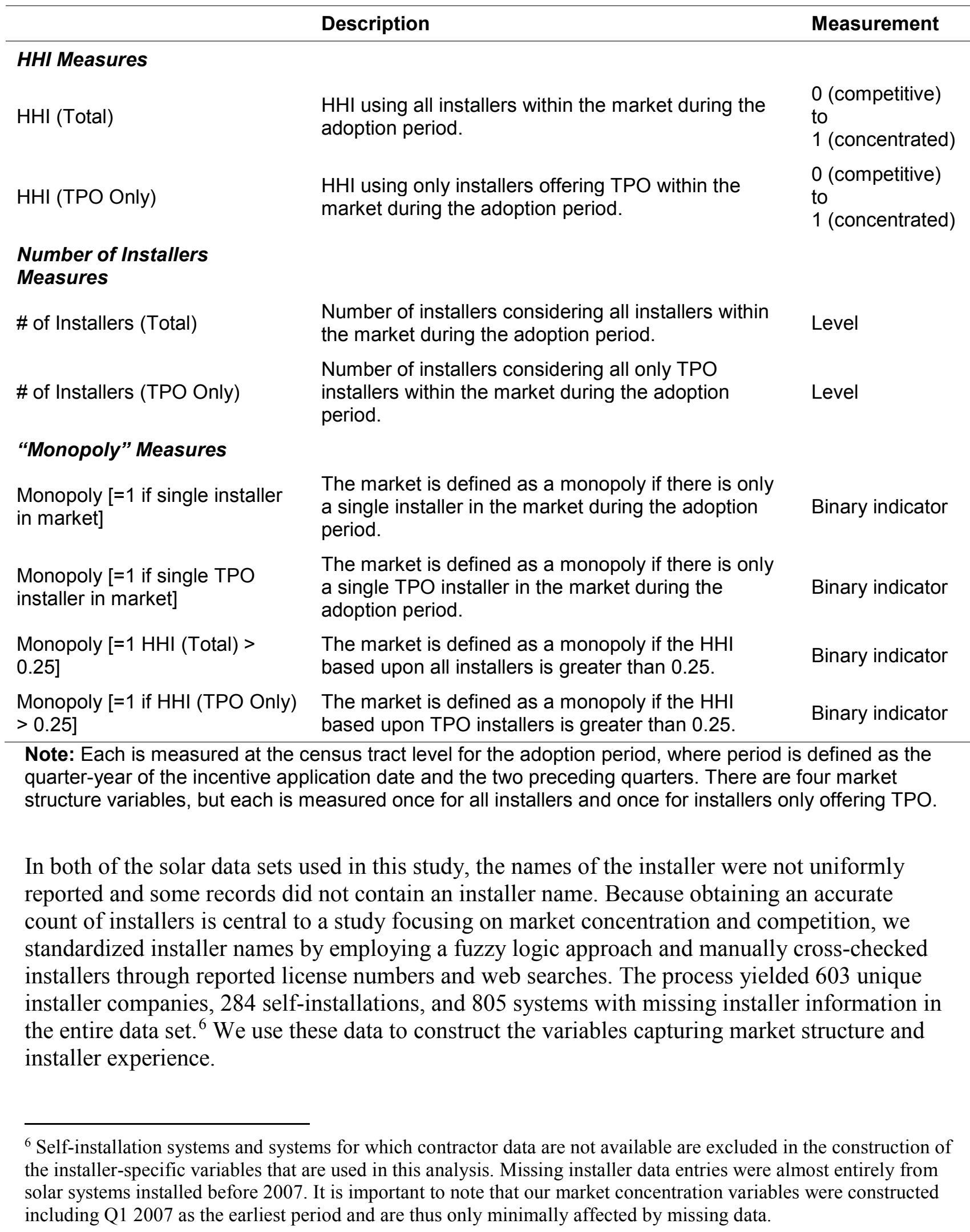


Following Hughes and Podolefsky (2015), we consider the incentive application date to be the best proxy for the solar adoption decision-making process and contract negotiation. We define the 'adoption period' using this date and the two preceding quarters to capture the activity of installers in the market at the time the contractor was actively pursuing the sale of a solar system and when homeowners were in the process of signing solar contracts and making the solar adoption decision.

We define market boundaries at the level of census tract because tracts are relatively permanent subdivisions of counties and form polygons that may be representative of solar marketers and installers targeting neighborhoods. Census tracts tend to have identifiable boundaries and present good proxies for "natural neighborhoods," i.e., what residents would subjectively define as neighborhood (Ross et al. 2004). Compared to zip codes, census tract boundaries are well defined and have the benefit to yield the collection of more reliable economic-demographic data.

To gather information on TPO solar system prices, we obtained TPO contracts for the SDG\&E territory through a non-disclosure agreement. The contracts provide information on the contract terms agreed upon between third parties and the TPO solar adopters. Reported prices for TPO systems in California that are publicly provided by the California Solar Initiative Program are known to be unreliable and inconsistent because they present the installer-reported appraised value of the system, as opposed to the actual price the consumer paid. Podolefsky (2013) empirically demonstrates potential over-reporting. As such, we use the transaction price as implied by contract terms agreed upon between the consumer and the third party leasing the panels. We follow Davidson, Steinberg, and Margolis (2015) and derive the net present cost (NPC) of each contract based upon monthly lease payments or PPA rates, estimated production (for PPAs), upfront payments, escalation rates, and contract term length. We apply a discounted cash flow methodology to calculate NPCs assuming a 10\% nominal discount rate (in our baseline specification) and $3 \%$ inflation. ${ }^{7}$

Lastly, we include a number of household-level and census tract-level control variables in our analysis. As such, we geocoded PV system locations and matched the installation data to census tract level demographic data from the U.S. Census Bureau American Community Survey (ACS 2009-2013, 5-year estimates). Furthermore, we calculate housing density as the number of single-family households per square kilometer of land in each census tract. We gather householdlevel building variables from San Diego County Assessor data and public record data providers.

\footnotetext{
${ }^{7}$ Note that we perform sensitivity analyses on the discount rate assumption (see Appendix), finding the results to be robust across a wide range of plausible discount rates.
} 


\subsection{Sampling Strategy}

By the end of Q1 2013, 4,725 TPO systems were installed within the SDG\&E territory. To obtain a sample of TPO contracts to transcribe that allowed us to obtain pricing information, we sampled TPO systems that were installed in sufficiently large markets to allow for the analysis of competition within a market. We consider markets suitable if they contain at least 30 singlefamily homes. Therefore, we omit TPO installations that are located in census tracts with less than 30 single-family homes, resulting in 4,706 systems remaining. We performed a stratified pseudo-random sampling method to select 750 contracts, which yielded 582 TPO contracts with enough data to calculate NPCs between 2008 and Q1 2013, stratified by year. ${ }^{8}$

Table 2 provides sample summary statistics of our primary variables of interest-price (or NPC) of TPOs in our sample and eight measures of market structure, defining markets at the census tract level. Table A-1 in the Appendix provides summary statistics for the full set of controls used in this analysis. See Figure A-1 in the Appendix for detailed maps of price, HHI, and installer count measures over time.

Table 2. Sample Summary Statistics of Market Concentration and System Price Variables

\begin{tabular}{|c|c|c|c|c|c|}
\hline & Mean & St. Deviation & Min & Max & $\begin{array}{l}\text { No. of } \\
\text { Obs. }\end{array}$ \\
\hline \multicolumn{6}{|l|}{ Price Measure (Net Present Cost) } \\
\hline NPC (\$/Watt) (10\% Discount Rate) & $\$ 3.22$ & $\$ 0.95$ & $\$ 0.84$ & $\$ 6.41$ & 581 \\
\hline \multicolumn{6}{|l|}{ HHI Measures } \\
\hline $\mathrm{HHI}$ (Total) & 0.295 & 0.253 & 0.055 & 1 & 581 \\
\hline HHI (TPO Only) & 0.492 & 0.333 & 0.085 & 1 & 581 \\
\hline \multicolumn{6}{|l|}{ Number of Installers Measures } \\
\hline \# of Installers (Total) & 6.844 & 4.682 & 1 & 30 & 581 \\
\hline \# of Installers (TPO Only) & 4.034 & 3.273 & 1 & 19 & 581 \\
\hline \multicolumn{6}{|l|}{ "Monopoly" Measures } \\
\hline Monopoly [ $=1$ if single installer in market] & 0.088 & 0.283 & 0 & 1 & 581 \\
\hline $\begin{array}{l}\text { Monopoly [ }=1 \text { if single TPO installer in } \\
\text { market] }\end{array}$ & 0.269 & 0.444 & 0 & 1 & 581 \\
\hline Monopoly [=1 HHI (Total) > 0.25] & 0.363 & 0.481 & 0 & 1 & 581 \\
\hline Monopoly [=1 if HHI (TPO Only) > 0.25] & 0.661 & 0.474 & 0 & 1 & 581 \\
\hline
\end{tabular}

\footnotetext{
${ }^{8}$ The sampling process aimed to achieve 600 usable contracts that correspond to sample statistics with a margin of error of $2.5 \%$ at a $95 \%$ confidence level. It is possible that the excluded/unusable contracts were from a subset of installers and not representative of all installers. This is not a concern for our analysis because it means that there could be measurement error in our dependent variable (as opposed to one of the covariates), and measurement error in the dependent variable does not produce bias in a regression analysis set up. The coefficient estimates are consistently estimated.
} 


\section{Empirical Strategy}

This section describes our empirical strategy for estimating the impact of market structure on pricing for residential solar PV TPO systems in the SDG\&E service territory. We take a reduced form approach and use IV regressions in an attempt to address the endogeneity of market structure. As such, the ability to identify a causal relationship between market structure and pricing relies upon the validity of our instruments. We also include a rich set of controls and fixed effects.

\subsection{Econometric Framework}

We take a reduced form approach to estimate the impact of market structure on residential solar PV TPO contract prices in the SDG\&E service territory using the following linear specification:

$$
P_{i}=\alpha+\beta_{1} \operatorname{CONC}_{j t}+\mathbf{X}_{i} \theta+\varphi_{k}+\lambda_{l}+\mu_{m}+\varepsilon_{i}
$$

where $P_{i}$ is the price (\$/watt), or net present cost, of system $i$ and $C O N C_{j t}$ represents a measure of installer concentration (or market structure) in census tract $j$ at time $t$. Measuring concentration in the eight different ways described in Section 3, we consider eight separate specifications to estimate the relationship between market structure and price. The matrix $\mathbf{X}_{i}$ includes control variables that differ across installations, markets, and time, $\varphi_{k}$ are module model fixed effects, $\lambda_{l}$ are installer fixed effects, $\mu_{m}$ are year by quarter time fixed effects, and $\varepsilon_{i}$ is a disturbance term.

We include PV module model and installer fixed effects in our specifications to account for time-invariant mean differences in prices across module model types and installers. It is possible that certain module model types are more expensive on average, all else equal, due to unobserved factors such as quality, branding, etc. Similarly, prices offered by various installers may differ on average due to branding, ancillary services, additional amenities, etc. Because there are some installations that were self-installed as well as some very small companies with only a few installations in our sample, we define installer fixed effects to include only installers with more than $5 \%$ of the market share in the previous two quarters.

The matrix of controls includes various system characteristics, house characteristics, local sociodemographics, and other market controls that could impact price. To account for price differences deriving from system characteristics, we include the rated system capacity (CSI rating) as reported in the incentive database, CSI rating squared, CSI rebate (adjusted for other incentives), ${ }^{9}$ a dummy if the installer is vertically integrated, ${ }^{10}$ dummy for the use of more than one inverter, and estimated year one system production $(\mathrm{kWh})$. The CSI rating $(\mathrm{kW})$ is reported in the CSI incentive database and captures system size as well as expected performance because it is a measure based upon design factor and other performance-impacting features. Similarly, estimated year one production $(\mathrm{kWh})$ captures the potential value of solar provided to the consumer as this directly captures projected utility bill reductions associated with the solar

\footnotetext{
${ }^{9}$ See Lobel, Pless, and van Benthem (forthcoming) for details on the motivation for adjusting the CSI rebate by other incentives that the installer receives as well as adjustment method employed.

${ }^{10} \mathrm{We}$ define a firm to be vertically integrated if it owns all major parts of the solar business, including capital, sales, installation, maintenance, and service, and the firm provides financing and arranging the incentive benefits. It is not vertically integrated (and assigned a zero) if a different party offers financing.
} 
installation. We use system characteristics that are reported in the CSI database and calculate the estimated year one production for each system using the National Renewable Energy

Laboratory's PVWatts tool. Furthermore, based on the reported data, we distinguish between the use of one inverter (equals 0 ) or more (equals 1 ) in the specification as this is a system design choice that could significantly increase price.

We include additional household level characteristics - square footage, number of beds, and number of baths - as proxies for electricity use in order to control for the potential value that solar provides to the consumer as well as factors that can impact pricing. ${ }^{11}$ Furthermore, we include a set of household socioeconomic and demographic variables measured at the Census tract level to account for the potential influence of bargaining power and negotiation skills of homeowners in the solar acquisition process as well as any marketing tactics or strategies that could have been used by installers when targeting certain neighborhoods: median income $(\$ 1,000 \mathrm{~s})$, median house value $(\$ 1,000 \mathrm{~s})$, and percentage of the population with a bachelor's degree.

A few additional control variables are included to capture market, installer, or geographic conditions that could affect price. First, single-family household density by census tract captures market size, which could contribute to firm behavior. This density measurement also aims to control for the availability of potential consumers to installers as they develop and target marketing strategies, or "scale economies."

To control for how difficult or easy it may be to break into a market, we include a market saturation variable that characterizes existing adoption levels of small residential solar systems in a market at the time the contractor is selling the solar system to the homeowner. Market saturation is defined as the cumulative number of installations in each census tract at the incentive application date divided by the number of single-family detached homes (multiplied by 100). Installation counts do not include systems installed under affordable housing projects or those installed under the new solar homes program, as we deem these to be distinct from the single-family residential market.

In addition, SDG\&E's residential electrical rates are structured in tiers in which baseline costs differ across four climate zones within the territory. This leads to a pronounced difference in the value proposition of solar for homeowners in coastal communities as opposed to inland communities. Therefore, we include an indicator variable that depicts whether the system is located in a coastal or an inland zone.

We also account for whether the module is domestically manufactured because this could impact the system-level value proposition as well as price. It is often recognized that solar panels manufactured in the United States as opposed to in some foreign regions are more expensive or perhaps differ in quality (Gillingham et al 2014). Although we include module model fixed effects, which largely overlaps with manufacturer, we include an indicator variable to specifically account for American manufactured solar panels when they were accredited under

\footnotetext{
${ }^{11}$ Retail electricity rates in San Diego follow a tiered structure such that the value of solar energy increases with energy usage. Thus it is plausible that contract prices are correlated with energy usage. We were unable to directly collect data on household energy usage, so we use household level characteristics as a proxy.
} 
the "Buy American" provision of the American Recovery and Reinvestment Act of 2009 (ARRA). We also categorized pre-2009 systems according to these accreditations.

Lastly, it is possible that an installer's experience level, or the number of systems installed by a contractor, can lead to system cost reductions as the contractor increases efficiency of operations. Some of these efficiencies, however, could also diminish over time due to "forgetting." We include a contractor experience variable that measures cumulative TPO installations by each installer within the SDG\&E territory up to the quarter-year of the incentive application date for each observation. We then follow Gillingham et al. (2014) and apply a 20\% depreciation rate per quarter to account for potential "forgetting."

\subsection{Identification}

Our main identification challenge in estimating the causal relationship between market structure and TPO system price is that market structure is endogenous. Unobserved shocks to cost and demand can affect both prices and thus market structure could be correlated with unobservables. Furthermore, the output of individual firms affects both prices and concentration. Lastly, there is a potential simultaneity bias if setting prices aggressively low deters entry or drives out other firms. A simple linear regression of price on concentration that does not account for such endogeneity could lead to biased estimates. While using number of firms instead of concentration as a measure of market structure provides the advantage of removing one of the sources of endogeneity - number of firms is not a function of endogenous firm output or revenues (Evans, Froeb, and Werden 1993) — such a specification would still suffer from correlated unobservables as a source of endogeneity.

There are two primary approaches for handling this endogeneity. The first method is to conduct a two-step estimation where the first stage estimates an equilibrium model that predicts the number of firms in a market. This generates a correction term that can be included in a second-stage regression of price on concentration. This has been used in some price-concentration studies (Manuszak and Moul 2008; Singh and Zhu 2008; Mazzeo 2002). However, this approach requires strong assumptions about the behavior of firms when characterizing the market structure in the first stage estimation.

Another approach is to find suitable instruments for market structure, or variables that are correlated with market structure but uncorrelated with unobservable factors that affect price. To date, studies examining the price-concentration relationship have had limited success due to the difficulty in finding suitable instruments. One could use lagged market structure as done in Evans, Froeb, and Werden (1993) and Davis (2005), but this is only valid under relatively stringent assumptions.

Instead, we isolate exogenous variation in concentration by using the percentage of single-family homes within a Census tract that are owner-occupied as an IV. Use of single-family percentage is justified as a valid instrument variable on theoretical grounds because we have no reason to believe that single-family percentage is correlated with unobservable factors that affect price whereas it is possible that homeowners who occupy their homes (rather than rent them to others) are more likely to consider adopting solar. As such, firms may target marketing strategies and adoption efforts based upon homeowner occupancy. We would expect to find a negative relationship between this variable and concentration: markets with a higher number of active 
firms (and thus a less concentrated market) are likely to have attracted firms because the market has a higher percentage of homes occupied by homeowners who are interested in saving money on their own utility bills. Indeed, our results indicate that it is a strong predictor of market structure in our first stage regression results with the expected sign, as described in Section 5, where we also demonstrate the validity of the instrument over multiple specifications. 


\section{Empirical Results}

It is often assumed that prices decrease as markets become more competitive; however, the relationship between competition and price is not necessarily trivial. That is, consumers in more competitive markets could face higher prices. When this occurs, the phenomenon is often attributed to theories related to firm entry deterrence strategy and dominant firms not engaging in price wars. This makes the question of how prices vary with competition in the solar market suitable for empirical testing. This section summarizes our empirical results.

\subsection{Main Results}

When instrumenting for the endogeneity of market structure, our results consistently show that consumers in more competitive markets face higher prices in the residential solar TPO market of the SDG\&E service territory across all eight measures of "market structure."

Table 3 presents the regression results when using HHI (Total) as the main variable of interest, iteratively adding controls and fixed effects across seven specifications. Column 7 presents the results for the preferred specification in which all controls and fixed effects are included. We find there to be a negative and statistically significant relationship (at the 5\% level) between HHI and price; an increase of the HHI from 0 to 1 results in a decrease of price by $\$ 1.06$ per watt, all else equal. Because a higher HHI represents a more concentrated (or less competitive) market, this implies that prices are lower in markets that are more concentrated (or prices are higher in more competitive markets).

Similarly, Table 4 presents the results when using HHI calculated just based upon TPO installers rather than all installers. Again, we find that prices are higher in markets with a lower HHI, or in markets that are less concentrated. 
Table 3. Main Instrumental Variable Regression Estimates of the Effect of HHI (Using all Installers in HHI Calculation)

\begin{tabular}{lccccccc}
\hline & $\mathbf{( 1 )}$ & $\mathbf{( 2 )}$ & $\mathbf{( 3 )}$ & $\mathbf{( 4 )}$ & $\mathbf{( 5 )}$ & $\mathbf{( 6 )}$ & $\mathbf{( 7 )}$ \\
\hline HHI (Total) & & & & & & & \\
& 0.006 & -0.261 & $-0.508^{*}$ & $-0.710^{* *}$ & $-0.669^{* *}$ & $-0.899^{\star *}$ & $-1.062^{* *}$ \\
& $(0.404)$ & $(0.294)$ & $(0.288)$ & $(0.285)$ & $(0.299)$ & $(0.359)$ & $(0.495)$ \\
& & & & & & & \\
\hline Module Model FE & & $\mathrm{x}$ & $\mathrm{x}$ & $\mathrm{x}$ & $\mathrm{x}$ & $\mathrm{x}$ & $\mathrm{x}$ \\
Installer FE & & & $\mathrm{x}$ & $\mathrm{x}$ & $\mathrm{x}$ & $\mathrm{x}$ & $\mathrm{x}$ \\
System Characteristics & & & & $\mathrm{x}$ & $\mathrm{x}$ & $\mathrm{x}$ & $\mathrm{x}$ \\
House Characteristics & & & & & $\mathrm{x}$ & $\mathrm{x}$ & $\mathrm{x}$ \\
Demographic Controls & & & & & & $\mathrm{x}$ & $\mathrm{x}$ \\
Other Controls & & & & & & & $\mathrm{x}$ \\
Year* ${ }^{*}$ Quarter FE & $\mathrm{x}$ & $\mathrm{x}$ & $\mathrm{x}$ & $\mathrm{x}$ & $\mathrm{x}$ & $\mathrm{x}$ & $\mathrm{x}$ \\
No. of Observations & 581 & 581 & 581 & 581 & 581 & 581 & 581 \\
\hline
\end{tabular}

Note: Installer FEs are dummies for contractors that hold $>5 \%$ of market share in our sample. System characteristics include estimated $\mathrm{Y} 1$ solar output, a dummy if the system has more than 1 inverter, CSI rating, CSI rating squared, and CSI rebate adjusted for MACRS and ITC. House characteristics include square footage, number of bathrooms, number of bedrooms, and built year. Demographic controls include median income, percentage of the population with a bachelor's degree, and median house value. Other controls include a dummy equal to one if the installer is vertically integrated, a dummy for ARRA (BuyAmerican), cumulative number of installations within a tract at the time of adoption, installer experience with TPOs, housing density by tract, and a dummy for systems that are coastal. Systems over $10 \mathrm{~kW}$ were omitted as well as systems with NPCs greater than $\$ 20 / \mathrm{kW}$ or less than $\$ 0.5 / \mathrm{kW}$. A $10 \%$ nominal discount rate is assumed for the NPC calculations. Asterisks denote ${ }^{*} p<0.10,{ }^{* *} p<0.05$, ${ }^{* * *} p$ $<0.01$. Standard errors clustered by census tract. 
Table 4. Main Instrumental Variable Regression Estimates of the Effect of HHI (TPO Installers Only in HHI Calculation)

\begin{tabular}{lccccccc}
\hline & $\mathbf{( 1 )}$ & $\mathbf{( 2 )}$ & $\mathbf{( 3 )}$ & $\mathbf{( 4 )}$ & $\mathbf{( 5 )}$ & $\mathbf{( 6 )}$ & $\mathbf{( 7 )}$ \\
\hline HHI (TPO Only) & & & & & & & \\
& 0.007 & -0.291 & $-0.571^{*}$ & $-0.803^{* *}$ & $-0.772^{* *}$ & $-0.968^{* *}$ & $-1.104^{* *}$ \\
& $(0.444)$ & $(0.331)$ & $(0.331)$ & $(0.336)$ & $(0.358)$ & $(0.402)$ & $(0.535)$ \\
\hline Module Model FE & & $\mathrm{x}$ & $\mathrm{x}$ & $\mathrm{x}$ & $\mathrm{x}$ & $\mathrm{x}$ & $\mathrm{x}$ \\
Installer FE & & & $\mathrm{x}$ & $\mathrm{x}$ & $\mathrm{x}$ & $\mathrm{x}$ & $\mathrm{x}$ \\
System Characteristics & & & & $\mathrm{x}$ & $\mathrm{x}$ & $\mathrm{x}$ & $\mathrm{x}$ \\
House Characteristics & & & & & $\mathrm{x}$ & $\mathrm{x}$ & $\mathrm{x}$ \\
Demographic Controls & & & & & & $\mathrm{x}$ & $\mathrm{x}$ \\
Other Controls & & & & & & & $\mathrm{x}$ \\
Year*Quarter FE & $\mathrm{x}$ & $\mathrm{x}$ & $\mathrm{x}$ & $\mathrm{x}$ & $\mathrm{x}$ & $\mathrm{x}$ & $\mathrm{x}$ \\
No. of Observations & 581 & 581 & 581 & 581 & 581 & 581 & 581 \\
\hline
\end{tabular}

Note: Installer FEs are dummies for contractors that hold $>5 \%$ of market share in our sample. System characteristics include estimated $\mathrm{Y} 1$ solar output, a dummy if the system has more than 1 inverter, CSI rating, CSI rating squared, and CSI rebate adjusted for MACRS and ITC. House characteristics include square footage, number of bathrooms, number of bedrooms, and built year. Demographic controls include median income, percentage of the population with a bachelor's degree, and median house value. Other controls include a dummy equal to one if the installer is vertically integrated, a dummy for ARRA (BuyAmerican), cumulative number of installations within a tract at the time of adoption, installer experience with TPOs, housing density by tract, and a dummy for systems that are coastal. Systems over $10 \mathrm{~kW}$ were omitted as well as systems with NPCs greater than $\$ 20 / \mathrm{kW}$ or less than $\$ 0.5 / \mathrm{kW}$. A $10 \%$ nominal discount rate is assumed for the NPC calculations. Asterisks denote ${ }^{*} p<0.10,{ }^{* *} p<0.05$, ${ }^{* * *} p$ $<0.01$. Standard errors clustered by census tract.

For both sets of results, our IV appears to be strong. The F-statistics for the excluded instrument are 23.04 and 23.05 for HHI (total) and HHI (TPO-only), respectively, which is well above the standard rule-of-thumb cut-off of 10. Furthermore, the first stage regression results demonstrate the relevance and strength of the IV in both cases. Table 5 presents the first stage regression estimates for the IV separately for each measure of HHI. The IV has a negative coefficient estimate in the first stage, as expected: more installers enter markets (and thus such markets have a lower HHI) with a higher percentage of single-family homes that are owner-occupied.

Furthermore, in both cases the IV is statistically significant at the $0.1 \%$ level, demonstrating that the IV is a strong predictor of HHI. ${ }^{12}$

\footnotetext{
${ }^{12}$ Furthermore, in both cases, the Kleibergen-Paap rk LM statistic demonstrates that our specifications pass both the under-identification test and the weak identification test when comparing the statistic to the Stock-Yogo weak ID test critical values.
} 
Table 5. Results for IV in First Stage Regressions

\begin{tabular}{|l|c|c|}
\hline Concentration measure used: & (1) & (2) \\
\hline $\begin{array}{l}\text { Instrument (\% of single-family homes that are owner } \\
\text { occupied) }\end{array}$ & $\mathrm{HHI}$ (Total) & $\begin{array}{c}\mathrm{HHI}(\mathrm{TPO} \\
\text { Only) }\end{array}$ \\
\hline & $-0.489^{* * *}$ & $-0.470^{* * *}$ \\
\hline F-Statistic & $(0.090)$ & $(0.098)$ \\
\hline No. of Observations & 29.23 & 29.24 \\
\hline
\end{tabular}

Table A6 in the appendix presents the estimates for the entire set of covariates. Some of the controls are statistically significant but mostly unremarkable. Perhaps most notably, we find that installer experience is also negatively related to price (and statistically significant at the 5\% level) and that vertically integrated firms tend to offer lower prices. This might suggest that firms can become more efficient or develop economies of scale with more experience in the market, enabling them to offer better deals.

Tables 6 and 7 present the IV regression estimates when measuring concentration by the two constructed "monopoly" HHI variables, demonstrating results that are consistent with our findings from Tables 3 and 4 . When including all controls and fixed effects (column 7 of each table), we find a negative and statistically significant relationship between concentration and price, suggesting that prices are lower in markets that are "monopolies" (or have less competition). Once again, our IV appears to be strong: it is statistically significant in the first stage regressions (with the expected sign), the specifications pass both the under- and weakidentification tests, and the F-statistics are sufficiently high in all cases. 
Table 6. Main Instrumental Variable Regression Estimates of the Effect of Monopoly on Price, Monopoly $=1$ if $\mathrm{HHI}$ (Total) $>0.25$

\begin{tabular}{|c|c|c|c|c|c|c|c|}
\hline & (1) & (2) & (3) & (4) & (5) & $(6)$ & (7) \\
\hline \multirow[t]{2}{*}{$\begin{array}{l}\text { Monopoly [=1 if HHI (Total) } \\
>0.25]\end{array}$} & 0.004 & -0.149 & $-0.292^{*}$ & $-0.407^{* *}$ & $-0.373^{* *}$ & $-0.488^{* *}$ & $-0.535^{\star *}$ \\
\hline & $(0.230)$ & $(0.168)$ & $(0.167)$ & $(0.167)$ & $(0.168)$ & $(0.201)$ & $(0.252)$ \\
\hline Module Model FE & & $x$ & $x$ & $x$ & $x$ & $x$ & $x$ \\
\hline Installer FE & & & $x$ & $x$ & $x$ & $x$ & $x$ \\
\hline System Characteristics & & & & $x$ & $x$ & $x$ & $x$ \\
\hline House Characteristics & & & & & $x$ & $x$ & $x$ \\
\hline Demographic Controls & & & & & & $x$ & $x$ \\
\hline Other Controls & & & & & & & $x$ \\
\hline Year*Quarter FE & $x$ & $x$ & $x$ & $x$ & $\mathrm{x}$ & $\mathrm{x}$ & $x$ \\
\hline No. of Observations & 582 & 582 & 582 & 582 & 582 & 582 & 582 \\
\hline
\end{tabular}

Note: Installer FEs are dummies for contractors that hold $>5 \%$ of market share in our sample. System characteristics include estimated Y1 solar output, a dummy if the system has more than 1 inverter, CSI rating, CSI rating squared, and CSI rebate adjusted for MACRS and ITC. House characteristics include square footage, number of bathrooms, number of bedrooms, and built year. Demographic controls include median income, percentage of the population with a bachelor's degree, and median house value. Other controls include a dummy equal to one if the installer is vertically integrated, a dummy for ARRA (BuyAmerican), cumulative number of installations within a tract at the time of adoption, installer experience with TPOs, housing density by tract, and a dummy for systems that are coastal. Systems over $10 \mathrm{~kW}$ were omitted as well as systems with NPCs greater than $\$ 20 / \mathrm{kW}$ or less than $\$ 0.5 / \mathrm{kW}$. A $10 \%$ nominal discount rate is assumed for the NPC calculations. Asterisks denote ${ }^{*} p<0.10,{ }^{* *} p<0.05,{ }^{* * *} p$ $<0.01$. Standard errors clustered by census tract. 
Table 7. Main Instrumental Variable Regression Estimates of the Effect of Monopoly on Price, Monopoly = 1 if HHI (TPO only) $>0.25$

\begin{tabular}{|c|c|c|c|c|c|c|c|}
\hline & (1) & (2) & (3) & (4) & (5) & (6) & (7) \\
\hline \multirow{2}{*}{$\begin{array}{l}\text { Monopoly [=1 if } \mathrm{HHI} \text { (TPO } \\
\text { Only) }>0.25]\end{array}$} & 0.007 & -0.260 & $-0.524^{*}$ & $-0.759^{* *}$ & $-0.729^{* *}$ & $-0.876^{* *}$ & $-1.168^{*}$ \\
\hline & $(0.419)$ & $(0.299)$ & $(0.314)$ & $(0.345)$ & $(0.367)$ & $(0.420)$ & $(0.697)$ \\
\hline Module Model FE & & $x$ & $x$ & $x$ & $x$ & $x$ & $x$ \\
\hline Installer FE & & & $x$ & $x$ & $x$ & $x$ & $x$ \\
\hline System Characteristics & & & & $x$ & $x$ & $x$ & $x$ \\
\hline House Characteristics & & & & & $x$ & $x$ & $x$ \\
\hline Demographic Controls & & & & & & $x$ & $x$ \\
\hline Other Controls & & & & & & & $x$ \\
\hline Year*Quarter FE & $x$ & $x$ & $x$ & $x$ & $x$ & $x$ & $x$ \\
\hline No. of Observations & 582 & 582 & 582 & 582 & 582 & 582 & 582 \\
\hline
\end{tabular}

Note: Installer FEs are dummies for contractors that hold $>5 \%$ of market share in our sample. System characteristics include estimated Y1 solar output, a dummy if the system has more than 1 inverter, CSI rating, CSI rating squared, and CSI rebate adjusted for MACRS and ITC. House characteristics include square footage, number of bathrooms, number of bedrooms, and built year. Demographic controls include median income, percentage of the population with a bachelor's degree, and median house value. Other controls include a dummy equal to one if the installer is vertically integrated, a dummy for ARRA (BuyAmerican), cumulative number of installations within a tract at the time of adoption, installer experience with TPOs, housing density by tract, and a dummy for systems that are coastal. Systems over $10 \mathrm{~kW}$ were omitted as well as systems with NPCs greater than $\$ 20 / \mathrm{kW}$ or less than $\$ 0.5 / \mathrm{kW}$. A $10 \%$ nominal discount rate is assumed for the NPC calculations. Asterisks denote ${ }^{*} p<0.10,{ }^{* *} p<0.05$, ${ }^{* * *} p$ $<0.01$. Standard errors clustered by census tract.

Tables A2 through A5 in the Appendix present the results for the other measures of "market structure," which consistently support the same conclusion: consumers face lower prices in more concentrated markets. Furthermore, in each case, the F-statistics are sufficiently high and the first stage regression results are strong.

Although our IVs appear to be strong, it is important to examine whether the IV regression results are actually different from the naïve results (non-instrumented) to better understand whether the IV is appropriately removing the bias. In Table 8 we compare the IV and naïve noninstrumented (Non-IV) regression results for four of our 'market structure' measures. We see that the estimates are significantly downward biased when the endogeneity issue is ignored, which demonstrates the severity of bias from ignoring the endogeneity of market structure in a regression analysis of this price-concentration relationship. 
Table 8. Comparing Instrumental Variable (IV) Regression Results to Non-IV Results for HHI Measures and "Monopoly" Defined by HHI Measures

\begin{tabular}{|c|c|c|c|c|c|c|c|c|}
\hline & (1) & (2) & (3) & (4) & (5) & (6) & (7) & (8) \\
\hline & \multicolumn{2}{|c|}{ HHI (Total) } & \multicolumn{2}{|c|}{ HHI (TPO Only) } & \multicolumn{2}{|c|}{$\begin{array}{l}\text { Monopoly [=1 if } \\
\text { HHI (Total) }>0.25]\end{array}$} & \multicolumn{2}{|c|}{$\begin{array}{c}\text { Monopoly [=1 if } \\
\text { HHI (TPO Only) > } \\
0.25]\end{array}$} \\
\hline & Non-IV & IV & Non-IV & IV & Non-IV & IV & Non-IV & IV \\
\hline \multirow[t]{2}{*}{ Concentration } & -0.238 & $-1.062^{* *}$ & $-0.340^{* *}$ & $-1.104^{\star *}$ & $-0.164^{*}$ & $-0.535^{\star *}$ & -0.060 & $-1.168^{*}$ \\
\hline & $(0.163)$ & $(0.495)$ & $(0.159)$ & $(0.535)$ & $(0.086)$ & $(0.252)$ & $(0.087)$ & $(0.697)$ \\
\hline No. of Observations & 581 & 581 & 581 & 581 & 581 & 581 & 581 & 581 \\
\hline
\end{tabular}

Note: Contractor FEs, Module Model FEs, and quarter by year time FEs are included in each regression. Contractor FEs are dummies for contractors that hold $>5 \%$ of market share in our sample. System characteristics include estimated Y1 solar output, a dummy if the system has more than 1 inverter, CSI rating, CSI rating squared, and CSI rebate adjusted for MACRS and ITC. House characteristics include square footage, number of bathrooms, number of bedrooms, and built year. Demographic controls include median income, percentage of the population with a bachelor's degree, and median house value. Other controls include a dummy if the installer is vertically integrated, a dummy for ARRA (BuyAmerican), cumulative number of installations within a tract at the time of adoption, installer experience with TPOs, housing density by tract, and a dummy for systems that are coastal. Systems over $10 \mathrm{~kW}$ were omitted as well as systems with NPCs greater than $\$ 20 / \mathrm{kW}$ or less than $\$ 0.5 / \mathrm{kW}$. A $10 \%$ nominal discount rate is assumed for the NPC calculations. Asterisks denote ${ }^{*} p<0.10,{ }^{* *} p<0.05,{ }^{* * *} p<0.01$. Standard errors clustered by census tract.

\subsection{Robustness Checks}

While finding consistent results across eight measures of market structure provides us with confidence that there is a statistically significant positive relationship between installer competition and pricing in this market - or, in other words, consumers face lower prices in more concentrated markets - there are alternative influences that could affect the results that should be ruled out. Furthermore, while the first stage regression results and high F-statistics from our regressions suggest that the IV is strong, some may question whether our IV sufficiently satisfies the exclusion restriction (i.e., that the IV is correlated with the error term), which is required for drawing causal inference in this empirical set-up.

The exclusion restriction formally states that the IV should not directly impact the dependent variable conditional on all exogenous variables in the model. That is, the only way in which the IV should affect prices is through the market structure channel conditional on the inclusion of the controls. While we include a rich set of controls and fixed effects in an attempt to address this and ensure that the only way in which our IV affects pricing is through the market structure channel, some may argue that there are still other factors that we are missing.

For example, it is possible that our IV is associated with historically higher property values and wealth so solar firms may disproportionately target wealthy areas because of a higher willingness to pay. This could translate into higher pricing, which would be consistent with higher prices in 
more competitive markets. ${ }^{13}$ While we control for demographic factors such as median income, education, and house values, wealth may not be fully captured.

To address this concern, we include an additional control variable that aims to capture disposable income. We include a "rent-adjusted income indicator," which is provided by CalEnvironScreen (OEHHA 2016). The indicator was calculated by subtracting the medium gross rent from the median household income based on the 2010-2014 ACS 5-year estimates. The indicator was proposed to capture the reality that the cost of living varies greatly across California and households with lower incomes spend a larger proportion of their income on housing.

Second, it is possible that high home occupancy rates could be influenced by the same unobserved shocks that affect market structure and pricing. In particular, the mix of renters to owners within a housing market could have changed with the onset of the Great Recession, particularly in places where property values declined and investors converted homes into rentals, which may be correlated with solar system pricing. ${ }^{14}$

In an attempt to address this, we include three additional "housing growth" variables as controls: the change in single family owner and renter occupied detached and attached building stock, the change in total housing stock in an area (includes single and multifamily), and the change in total housing stock that is occupied in an area (includes single and multifamily). We calculated the housing growth based on differences in housing stock from 2010 to 2014 using the 2006-2010 and 2010-2014 ACS data sets. The results in Table 9 show that our findings generally do not change for any of eight "market structure" measures when including the housing growth and disposable income (or "wealth") controls. Furthermore, the first stage results remain strong and the F-statistics are sufficiently high.

Table 9. Adding Disposable Income and Housing Growth Controls

\begin{tabular}{|c|c|c|c|c|c|c|c|c|}
\hline & (1) & (2) & (3) & (4) & (5) & (6) & (7) & (8) \\
\hline $\begin{array}{l}\text { Concentration } \\
\text { measure } \\
\text { used: }\end{array}$ & $\begin{array}{c}\text { HHI } \\
\text { (Total) }\end{array}$ & $\begin{array}{l}\text { HHI } \\
\text { (TPO } \\
\text { Only) }\end{array}$ & $\begin{array}{c}\text { \# of } \\
\text { Installers } \\
\text { (Total) }\end{array}$ & $\begin{array}{c}\text { \# of } \\
\text { Installers } \\
\text { (TPO } \\
\text { Only) }\end{array}$ & $\begin{array}{c}\text { Monopoly } \\
\text { [=1 if HHI } \\
(\text { Total) }> \\
0.25]\end{array}$ & $\begin{array}{c}\text { Monopoly } \\
\text { [=1 if HHI } \\
\text { (TPO Only) } \\
>0.25]\end{array}$ & $\begin{array}{c}\text { Monopoly } \\
\text { [=1 if } \\
\text { single } \\
\text { installer }]\end{array}$ & $\begin{array}{c}\text { Monopoly } \\
\text { [=1 if } \\
\text { single TPO } \\
\text { installer] }\end{array}$ \\
\hline \multirow[t]{2}{*}{ Concentration } & $-0.985^{\star *}$ & $-1.103^{*}$ & $0.075^{\star}$ & $0.152^{*}$ & $-0.498^{* *}$ & $-1.111^{*}$ & $-1.440^{*}$ & $-1.081^{*}$ \\
\hline & $(0.485)$ & $(0.565)$ & $(0.040)$ & $(0.087)$ & $(0.249)$ & $(0.674)$ & $(0.773)$ & $(0.584)$ \\
\hline F-Statistic & 43.37 & 30.78 & 30.05 & 16.24 & 44.82 & 8.83 & 12.24 & 14.80 \\
\hline $\begin{array}{l}\text { No. of } \\
\text { Observations }\end{array}$ & 563 & 563 & 563 & 563 & 563 & 563 & 563 & 563 \\
\hline
\end{tabular}

\footnotetext{
${ }^{13}$ We thank an anonymous referee for this useful insight and improvement to the paper.

${ }^{14}$ For instance, see this news article here: http://www.usnews.com/news/articles/2014/08/27/mix-of-renter-ownerneighborhoods-increased-between-2000-and-2010.
} 
Third, it is still possible that the IV is correlated with the error terms. As such, we searched for additional IVs and use "For-Sale Inventory," which is provided by Zillow Data (Zillow 2016). It is the median of weekly for-sale homes within a zip code for a given month (per single family households within a zip code). Contractors might be less likely to enter areas where ownership overturn rates are high. The results presented in Table 10 show that our findings hold when using both IVs, and the first stage results confirm that there are statistically fewer contractors where there are more houses for sale. The first stage results and F-statistics suggest that both IVs are consistently strong across the various measures of market structure.

Table 10. Using an Additional IV ("Homes For Sale Inventory")

\begin{tabular}{|c|c|c|c|c|c|c|c|c|}
\hline & (1) & (2) & (3) & (4) & (5) & (6) & (7) & (8) \\
\hline $\begin{array}{l}\text { Concentration } \\
\text { measure used: }\end{array}$ & $\begin{array}{l}\text { HHI } \\
\text { (Total) }\end{array}$ & $\begin{array}{l}\text { HHI } \\
\text { (TPO } \\
\text { Only) }\end{array}$ & $\begin{array}{c}\text { \# of } \\
\text { Installers } \\
\text { (Total) }\end{array}$ & $\begin{array}{c}\text { \# of } \\
\text { Installers } \\
\text { (TPO } \\
\text { Only) }\end{array}$ & $\begin{array}{c}\text { Monopoly } \\
\text { [=1 if HHI } \\
(\text { Total) }> \\
0.25]\end{array}$ & $\begin{array}{c}\text { Monopoly } \\
\text { [=1 if HHI } \\
\text { (TPO } \\
\text { Only) > } \\
0.25]\end{array}$ & $\begin{array}{c}\text { Monop } \\
\text { oly [=1 } \\
\text { if single } \\
\text { installer } \\
]\end{array}$ & $\begin{array}{c}\text { Monopo } \\
\text { ly [=1 if } \\
\text { single } \\
\text { TPO } \\
\text { installer } \\
\text { ] }\end{array}$ \\
\hline \multirow[t]{2}{*}{ Concentration } & $-1.492^{* * *}$ & $1.561^{* \star *}$ & $0.099^{* \star *}$ & $0.195^{\star \star \star}$ & $-0.711^{* * *}$ & $-1.462^{* *}$ & $-2.335^{\star *}$ & $-1.598^{* *}$ \\
\hline & $(0.504)$ & $(0.521)$ & $(0.029)$ & $(0.065)$ & $(0.250)$ & $(0.578)$ & $(0.984)$ & $(0.625)$ \\
\hline F-Statistic & 27.08 & 20.193 & 27.87 & 14.22 & 25.88 & 7.11 & 6.51 & 8.94 \\
\hline $\begin{array}{l}\text { No. of } \\
\text { Observations }\end{array}$ & 484 & 484 & 484 & 484 & 484 & 484 & 484 & 484 \\
\hline
\end{tabular}

Lastly, it is possible that our results are driven by our discount rate assumption. To be sure this is not true, we show that our findings are robust to various discount rate assumptions (relative to our main results with the original IV and controls) (Table A7). With a much lower discount rate than our original $10 \%$ baseline assumption, the results are consistent. When we increase the discount rate, we begin to lose significance in some cases, but such high discount rate assumptions beyond what we demonstrate in Table A7 are not realistic from the perspective of the firm. Nonetheless, it is important to note that our findings are just slightly sensitive to higher discount rate assumptions. 


\section{Discussion and Conclusions}

In this paper, we explore the impact of market structure on prices in the residential solar PV TPO market in the SDG\&E service territory in California. From a theoretical perspective, the sign and magnitude of the effect of market concentration, or "market structure," on prices are ambiguous. Increases in concentration may enable firms to increase markups, but it is also possible that increases in market share lead firms to lower prices when competing for customers. This motivated our empirical analysis of the price-concentration relationship in the SDG\&E residential solar PV TPO market.

We take a reduced form approach and attempt to isolate exogenous variation in market structure by estimating IV regressions. Our analysis shows that residential solar PV prices - as measured by the net present cost of the contract terms agreed upon between consumers and TPO providers - in the first years after the emergence of the third party market are higher in more competitive markets. Across eight measures of market concentration and structure, we find evidence that TPO contract prices are lower in more concentrated, or less competitive, markets (defined by census tracts).

The price-concentration relationship has been widely studied in various markets. These econometric studies are mostly found in the industrial organization literature and the primary objective is to explore how concentration is related to market power by asking whether firms can set prices above their marginal costs. Many papers find a positive correlation between market concentration and prices; however, many of them ignore the endogeneity of market structure, which biases the results because unobserved shocks to cost and demand could affect both prices and market structure. On the other hand, some analyses find that there is no evidence of a positive and significant relationship between prices and concentration.

Our results are contrary to the common assumption that competition leads to lower prices. There are at least two potential explanations for our findings. First, our results could suggest that firms are conducting entry deterrence strategies. It is possible that firms are setting low prices that are below potential competitors' marginal costs, which could deter entrants and ensure a larger market share. In other words, firms might be prioritizing growth in the near term with the belief that larger market share will yield greater profits later on. Similar firm behavior has already been observed in upstream markets in international module production (Feldman et al. 2016). Alternatively, Porter (1980) has described firm strategy where, in a competitive environment, firms seek to differentiate product offerings so as to not compete strictly on price. In the solar market, this could be observed via touting more efficient or premium panels, or by providing additional services. Second, there could be a group of dominant firms (with a competitive fringe), and the dominant firms may occasionally engage in price wars. If this is true, prices should be lower in more concentrated markets during the price wars (Salinger 1990).

The solar market in California has (at least) one feature that potentially sets it apart from other markets, especially solar markets in areas outside of California. Under the California Solar Initiative, any solar system that applied for an incentive was included in a publicly accessible solar spreadsheet on the California Solar Statistics website (CSI 2016). The spreadsheet includes biweekly updated information about its zip code, system size, reported costs, and installer name as well as details of module and inverter models. This information is for all to see, including 
competitors and future customers, and thus one might assume that the level of transparency leads to greater price pressure and more uniform prices (Austin and Gravelle 2007). However, transparency does not necessarily lead to price decreases. Installers may fear a race to the bottom if competing on price and decide to differentiate themselves through quality of service to maintain business in a market. Second, because installers are more informed about competitors' activities, they could strategically use the information and become tougher bargainers with customers (e.g., Albæk et al. 1997). In this market context, however, prices reported for TPO systems present unreliable indicators because they do often not represent the actual price paid by customers. This issue may also not be known by all market actors interested in using the information. It is therefore unclear what the level of transparency could mean for competition and prices in this market.

Though we have noted several plausible explanations of our findings (entry deterrence, growth strategies, price wars), future work can demonstrate the validity of the explanations. In part, this is because the terms of our data agreements prohibit us from identifying prices or strategies of individual firms. For example, one could use fixed effects for each firm in the data as well as use interactive effects for the unique services that large solar firms provide as a way of identifying firm-level strategy. Additional future work could include extending the analysis to include more recent data or to cover additional markets, especially those outside of California.

This paper adds to a growing emphasis on understanding supply-side factors in scaling up solar markets in the residential sector. Generally, solar markets have become more competitive over the same time period that solar technology costs decreased. While solar system hard costs have come down with the growth of the solar market, our research suggests that the path of cost development of soft costs (associated with acquisition, transaction, profits, etc.) is more nuanced in early market development of TPO solar systems. While we are unable to generalize the results to other regions or to how markets might evolve as solar investment continues to increase, our findings demonstrate that evolving markets can behave in unexpected ways. The introduction of solar as a service and the associated repositioning of market actors to establish such business models and maintain and grow business means that consumers could be vulnerable to market structure effects. Policymakers can consider these issues when designing markets and have the data needed to make informed decisions. 


\section{References}

ACS (U.S. Census Bureau American Community Survey). 2015. "2011-2015 ACS 5-Year Data Profiles.” https://www.census.gov/acs/www/data/data-tables-and-tools/dataprofiles/2015/.

ACS (U.S. Census Bureau American Community Survey). 2014. "2010-2014 ACS 5-Year Data Profiles." https://www.census.gov/acs/www/data/data-tables-and-tools/dataprofiles $/ 2014 /$.

ACS (U.S. Census Bureau American Community Survey). 2013. "2009-2013 ACS 5-Year Data Profiles.” https://www.census.gov/acs/www/data/data-tables-and-tools/dataprofiles/2013/.

ACS (U.S. Census Bureau American Community Survey). 2010. "2006-2010 ACS 5-Year Data Profiles."

Albæk, Svend, Peter Møllgaard, and Per B. Overgaard. 1997. "Government Assisted Oligopoly Coordination? A Concrete Case." Journal of Law and Economics 45:429-43. http://dx.doi.org/10.1111/1467-6451.00057.

Austin, D. Andrea, and Jane G. Gravelle. 2007. Does Price Transparency Improve Market Efficiency? Implications of Empirical Evidence in Other Markets for the Health Sector. Order Code RL34101. Washington, D.C.: Congressional Research Service. https://fas.org/sgp/crs/secrecy/RL34101.pdf.

Barbose, Galen L. and Naïm Darghouth. 2015. Tracking the Sun VIII: The Installed Price of Residential and Non-Residential Photovoltaic Systems in the United States. LBNL188238. Berkeley, California: Lawrence Berkeley National Laboratory. https://emp.lbl.gov/sites/all/files/lbnl-188238_2.pdf.

Borenstein, Severin. 1985. "Price Discrimination in Free-Entry Markets." The Rand Journal of Economics 16(3):380-97.

OEHHA (California Office of Environmental Health Hazard Assessment). 2016. "CalEnviroScreen 3.0 Draft Results." Released September 6. http://oehha.ca.gov/media/downloads/calenviroscreen/document/ces30draftresults.xlsx.

CSI (California Solar Initiative). 2016. “Monthly, Quarterly, and Annual Statistics.” Last updated November 17. https://www.californiasolarstatistics.ca.gov/reports/monthly_stats/.

CSI (California Solar Initiative). 2015. “2015 Working Data Set.” Accessed November. www.californiasolarstatistics.ca.gov/.

Davidson, Carolyn, and Robert Margolis. 2015. Selecting Solar: Insights into Residential Photovoltaic (PV) Quote Variation. NREL/TP-6A20-64792. Golden, CO: National Renewable Energy Laboratory. http://www.nrel.gov/docs/fy16osti/64792.pdf. 
Davidson, Carolyn, Daniel Steinberg, and Robert Margolis. 2015. "Exploring the Market for Third-Party-Owned Residential Photovoltaic Systems: Insights from Lease and PowerPurchase Agreement Contract Structures and Costs in California." Environmental Research Letters 10(2). http://dx.doi.org/10.1088/1748-9326/10/2/024006.

Davis, Peter. 2005. "The Effect of Local Competition on Admission Prices in the U.S. Motion Picture Exhibition Market." The Journal of Law and Economics 48(2):677-708. http://dx.doi.org/10.1086/428018.

Drury, Easan, Mackay Miller, Charles M. Macal, Diane J. Graziano, Donna Heimiller, Jonathan Ozik, and Thomas D. Perry IV. 2012. "The Transformation of Southern California's Residential Photovoltaics Market through Third-party Ownership.” Energy Policy 42:681-90. http://dx.doi.org/10.1016/j.enpol.2011.12.047.

CEC (California Energy Commission). 2011. "ERP (Emerging Renewables Program) Data." http://www.energy.ca.gov/renewables/emerging_renewables/.

Evans, William N., Luke M. Froeb, and Gregory J. Werden. 1993. "Endogeneity in the Concentration-Price Relationship: Causes, Consequences, and Cures.” The Journal of Industrial Economics 41(4):431-38.

Gillingham, Kenneth, Hao Deng, Ryan Wiser, Naïm Darghouth, Gregory Nemet, Galen Barbose, Varun Rai, and C.G. Dong. 2014. Deconstructing Solar Photovoltaic Pricing: The Role of Market Structure, Technology, and Policy. Berkeley, California: Lawrence Berkeley National Laboratory. https://emp.lbl.gov/sites/all/files/PV_Pricing_Final.pdf.

Kann, Shayle. 2013. U.S. Residential Solar PV Financing: The Vendor, Installer and Financier Landscape 2013-2016. Boston: GTM Research.

Holmes, Thomas J. 1989. "The Effects of Third-Degree Price Discrimination in Oligopoly." The American Economic Review 79(1):244-50.

Hughes, Jonathan E., and Molly Podolefsky. 2015. "Getting Green with Solar Subsidies: Evidence from the California Solar Initiative." Journal of the Association of Environmental and Resource Economists 2(2):235-75. http://dx.doi.org/10.1086/681131.

Lobel, R., Jacquelyn Pless, and A. van Benthem. Forthcoming. "The Surprising Pass-Through of Solar Subsidies."

Manuszak, Mark. D., and Charles C. Moul. 2008. "Prices and Endogenous Market Structure in Office Supply Superstores." The Journal of Industrial Economics 56(1):94-112. http://dx.doi.org/10.1111/j.1467-6451.2008.00334.x.

Mazzeo, Michael J. 2002. "Competitive Outcomes in Product-Differentiated Oligopoly." The Review of Economics and Statistics 84(4):716-28. http://dx.doi.org/10.1162/003465302760556521. 
Morrison, Steven A., and Clifford Winston. 1990. "The Dynamics of Airline Pricing and Competition." American Economic Review 80(2):389-93.

NEM Interconnection Data (NEM Currently Interconnected Data Set). Available from www.californiasolarstatistics.ca.gov/. Accessed November 2015.

Nemet, Gregory, Eric O’Shaughnessy, Ryan H. Wiser, Naïm R. Darghouth, Galen L. Barbose, Kenneth Gillingham, and Varun Rai. 2016. Characteristics of Low-Priced Solar Photovoltaic Systems in the U.S. LBNL-1004062. Berkeley, California: Lawrence Berkeley National Laboratory. https://emp.lbl.gov/sites/all/files/lbnl-1004062.pdf.

Podolefsky, Molly. 2013. Tax Evasion and Subsidy Pass-Through under the Solar Investment Tax Credit. Discussion Papers in Economics. Working Paper No. 13-05. Boulder: University of Colorado at Boulder. http://www.colorado.edu/econ/papers/Wps-13/wp1305/wp13-05.pdf

Porter, M.E. 1980. Competitive Strategy: Techniques for Analyzing Industries and Competitors. New York: Free Press.

Rai, Varun, and Benjamin Sigrin. 2013. "Diffusion of Environmentally-Friendly Energy Technologies: Buy versus Lease Differences in Residential PV Markets.” Environmental Research Letters 8(1). http://dx.doi.org/10.1088/1748-9326/8/1/014022.

Ross, Nancy A., Stéphane Tremblay, and Katie Graham. 2004. "Neighbourhood Influences on Health in Montréal, Canada.” Social Science \& Medicine 59(7):1485-94. http://dx.doi.org/10.1016/j.socscimed.2004.01.016.

Salinger, Michael. 1990. "The Concentration-Margins Relationship Reconsidered." In Brookings Papers: Microeconomics 1990, 287-335. Washington, D.C.: Brookings Institution. https://www.brookings.edu/wp-content/uploads/1990/01/1990 bpeamicro_salinger.pdf

San Diego County Assessor. 2012. "Parcel Property Characteristics." https://arcc.sdcounty.ca.gov/Pages/default.aspx.

SEIA (Solar Energy Industries Association). 2016. U.S. Solar Market Insight Report Q2 2016. Washington, D.C.: Solar Energy Industries Association.

Shih, L.H., and T.Y. Chou. 2011. "Customer Concerns about Uncertainty and Willingness to Pay in Leasing Solar Power Systems." International Journal of Environmental Science \& Technology 8(3)523-32. http://dx.doi.org/10.1007/BF03326238.

Singh, Vishal, and Ting Zhu. 2008. "Pricing and Market Concentration in Oligopoly Markets." Marketing Science 27(6):1020-1035. 
Weiss, Leonard W. 1989. "Why Study Concentration and Price?" In Concentration and Price, edited by Leonard W. Weiss, 1-16. Cambridge, Massachusetts: MIT Press.

Zillow. 2016. "For Sale Inventory (Smoothed): Median of Weekly Snapshot of For-Sale Homes Within a Region for a Given Month.” Accessed October.

http://www.zillow.com/research/data/. 


\section{Appendix}

Table A-1. Summary Statistics of All Variables

\begin{tabular}{|c|c|c|c|c|c|}
\hline & Mean & $\begin{array}{c}\text { St. } \\
\text { Deviation }\end{array}$ & Min & Max & $\begin{array}{c}\text { No. of } \\
\text { Observations }\end{array}$ \\
\hline NPC (\$/Watt) (10\% Discount Rate) & $\$ 3.22$ & $\$ 0.95$ & $\$ 0.84$ & $\$ 6.41$ & 581 \\
\hline $\mathrm{HHI}$ (Total) & 0.295 & 0.253 & 0.055 & 1 & 581 \\
\hline HHI (TPO Only) & 0.492 & 0.333 & 0.085 & 1 & 581 \\
\hline \# of Installers (Total) & 6.843 & 4.682 & 1 & 30 & 581 \\
\hline \# of Installers (TPO Only) & 4.034 & 3.273 & 1 & 19 & 581 \\
\hline $\begin{array}{l}\text { Monopoly [=1 if single installer in } \\
\text { market] }\end{array}$ & 0.088 & 0.283 & 0 & 1 & 581 \\
\hline $\begin{array}{l}\text { Monopoly [=1 if single TPO installer } \\
\text { in market] }\end{array}$ & 0.269 & 0.444 & 0 & 1 & 581 \\
\hline Monopoly [=1 HHI (Total) > 0.25] & 0.363 & 0.481 & 0 & 1 & 581 \\
\hline $\begin{array}{l}\text { Monopoly [=1 if HHI (TPO Only) > } \\
0.25]\end{array}$ & 0.661 & 0.474 & 0 & 1 & 581 \\
\hline Buy American (ARRA indicator) & 0.585 & 0.493 & 0 & 1 & 581 \\
\hline Cumulative installations & 3.849 & 5.345 & 0.094 & 68.234 & 581 \\
\hline Installer experience & 25.807 & 24.603 & 0.661 & 109.260 & 581 \\
\hline $\begin{array}{l}\text { Integrated [=1 if vertically } \\
\text { integrated] }\end{array}$ & 0.387 & 0.488 & 0 & 1 & 581 \\
\hline Single-family house density & 311.08 & 223.691 & 0.722 & 1030.594 & 581 \\
\hline Coastal (indicator) & 0.418 & 0.494 & 0 & 1 & 581 \\
\hline Median income $(\$ 1,000 s)$ & $\$ 92.75$ & $\$ 32.49$ & $\$ 28.04$ & $\$ 201.25$ & 581 \\
\hline$\%$ with bachelor's degree & $43.66 \%$ & $17.74 \%$ & $5.70 \%$ & $81.75 \%$ & 581 \\
\hline Median house value $(\$ 1,000 s)$ & $\$ 539.79$ & $\$ 203.21$ & $\$ 107.10$ & $\$ 1,000.00$ & 581 \\
\hline House size (square feet) & 2566 & 946.76 & 763 & 7565 & 581 \\
\hline Number of bathrooms & 2.793 & 0.898 & 0.3 & 6.5 & 581 \\
\hline Number of bedrooms & 3.780 & 0.865 & 1 & 7 & 581 \\
\hline Built year & 1984 & 16 & 1925 & 2012 & 581 \\
\hline Year 1 estimated solar production & 8173 & 2903 & 2216 & 16458 & 581 \\
\hline More than 1 inverter [=1 if yes] & 0.108 & 0.311 & 0 & 1 & 581 \\
\hline CSI rating & 4.752 & 1.673 & 1.390 & 8.70 & 581 \\
\hline CSI rating squared & 25.377 & 17.078 & 1.932 & 75.794 & 581 \\
\hline $\begin{array}{l}\text { CSI rebate (adjusted by ITC and } \\
\text { MACRS) }\end{array}$ & 0.202 & 0.239 & 0.073 & 1.095 & 581 \\
\hline $\begin{array}{l}\text { Percent of households that are } \\
\text { owned }\end{array}$ & 0.725 & 0.162 & 0.081 & 0.973 & 581 \\
\hline
\end{tabular}


Table A-2. Main Instrumental Variable Regression Estimates of the Effect of Number of Installers (All Installers) on Price

\begin{tabular}{lccccccc}
\hline & $(\mathbf{1})$ & $\mathbf{( 2 )}$ & $\mathbf{( 3 )}$ & $\mathbf{( 4 )}$ & $\mathbf{( 5 )}$ & $\mathbf{( 6 )}$ & $\mathbf{( 7 )}$ \\
\hline \# of Installers (Total) & & & & & & & \\
& -0.0004 & 0.015 & $0.030^{*}$ & $0.043^{* *}$ & $0.044^{* *}$ & $0.059^{* *}$ & $0.076^{*}$ \\
& $(0.023)$ & $(0.107)$ & $(0.017)$ & $(0.017)$ & $(0.020)$ & $(0.026)$ & $(0.040)$ \\
& & & & & & & \\
\hline Module Model FE & & $\mathrm{x}$ & $\mathrm{x}$ & $\mathrm{x}$ & $\mathrm{x}$ & $\mathrm{x}$ & $\mathrm{x}$ \\
Installer FE & & & $\mathrm{x}$ & $\mathrm{x}$ & $\mathrm{x}$ & $\mathrm{x}$ & $\mathrm{x}$ \\
System Characteristics & & & & $\mathrm{x}$ & $\mathrm{x}$ & $\mathrm{x}$ & $\mathrm{x}$ \\
House Characteristics & & & & & $\mathrm{x}$ & $\mathrm{x}$ & $\mathrm{x}$ \\
Demographic Controls & & & & & & $\mathrm{x}$ & $\mathrm{x}$ \\
Other Controls & & & & & & & $\mathrm{x}$ \\
Year*Quarter FE & $\mathrm{x}$ & $\mathrm{x}$ & $\mathrm{x}$ & $\mathrm{x}$ & $\mathrm{x}$ & $\mathrm{x}$ & $\mathrm{x}$ \\
No. of Observations & 581 & 581 & 581 & 581 & 581 & 581 & 581 \\
\hline
\end{tabular}

Note: Installer FEs are dummies for contractors that hold $>5 \%$ of market share in our sample. System characteristics include estimated Y1 solar output, a dummy if the system has more than 1 inverter, CSI rating, CSI rating squared, and CSI rebate adjusted for MACRS and ITC. House characteristics include square footage, number of bathrooms, number of bedrooms, and built year. Demographic controls include median income, percentage of the population with a bachelor's degree, and median house value. Other controls include a dummy equal to one if the installer is vertically integrated, a dummy for ARRA (BuyAmerican), cumulative number of installations within a tract at the time of adoption, installer experience with TPOs, housing density by tract, and a dummy for systems that are coastal. Systems over $10 \mathrm{~kW}$ were omitted as well as systems with NPCs greater than $\$ 20 / \mathrm{kW}$ or less than $\$ 0.5 / \mathrm{kW}$. A $10 \%$ nominal discount rate is assumed for the NPC calculations. Asterisks denote ${ }^{*} p<0.10,{ }^{* *} p<0.05$, ${ }^{* * *} p<0.01$. Standard errors clustered by census tract. 
Table A-3. Main Instrumental Variable Regression Estimates of the Effect of Number of Installers (Installing TPO Only) on Price

\begin{tabular}{|c|c|c|c|c|c|c|c|}
\hline & (1) & (2) & (3) & (4) & (5) & (6) & (7) \\
\hline \# of Installers (TPO Only) & $\begin{array}{l}-0.001 \\
(0.041)\end{array}$ & $\begin{array}{c}0.028 \\
(0.032)\end{array}$ & $\begin{array}{c}0.056^{*} \\
(0.032)\end{array}$ & $\begin{array}{l}0.080^{* *} \\
(0.034)\end{array}$ & $\begin{array}{l}0.084^{* *} \\
(0.039)\end{array}$ & $\begin{array}{l}0.120^{* *} \\
(0.057)\end{array}$ & $\begin{array}{l}0.164^{*} \\
(0.098)\end{array}$ \\
\hline Module Model FE & & $x$ & $x$ & $x$ & $x$ & $x$ & $x$ \\
\hline Installer FE & & & $x$ & $x$ & $x$ & $x$ & $x$ \\
\hline System Characteristics & & & & $x$ & $x$ & $x$ & $x$ \\
\hline House Characteristics & & & & & $x$ & $x$ & $x$ \\
\hline Demographic Controls & & & & & & $x$ & $x$ \\
\hline Other Controls & & & & & & & $x$ \\
\hline Year ${ }^{\star}$ Quarter FE & $x$ & $x$ & $x$ & $x$ & $x$ & $x$ & $x$ \\
\hline No. of Observations & 581 & 581 & 581 & 581 & 581 & 581 & 581 \\
\hline \multicolumn{8}{|c|}{$\begin{array}{l}\text { Note: Installer FEs are dummies for contractors that hold }>5 \% \text { of market share in our sample. System } \\
\text { characteristics include estimated Y1 solar output, a dummy if the system has more than } 1 \text { inverter, CSI } \\
\text { rating, CSI rating squared, and CSI rebate adjusted for MACRS and ITC. House characteristics include } \\
\text { square footage, number of bathrooms, number of bedrooms, and built year. Demographic controls } \\
\text { include median income, percentage of the population with a bachelor's degree, and median house value. } \\
\text { Other controls include a dummy equal to one if the installer is vertically integrated, a dummy for ARRA } \\
\text { (BuyAmerican), cumulative number of installations within a tract at the time of adoption, installer } \\
\text { experience with TPOs, housing density by tract, and a dummy for systems that are coastal. Systems } \\
\text { over } 10 \mathrm{~kW} \text { were omitted as well as systems with NPCs greater than } \$ 20 / \mathrm{kW} \text { or less than } \$ 0.5 / \mathrm{kW} \text {. A } \\
10 \% \text { nominal discount rate is assumed for the NPC calculations. Asterisks denote }{ }^{*} p<0.10,{ }^{* *} p<0.05 \text {, }\end{array}$} \\
\hline
\end{tabular}


Table A-4. Main Instrumental Variable Regression Estimates of the Effect of "Monopoly Based on \# of Installations" on Price

\begin{tabular}{|c|c|c|c|c|c|c|c|}
\hline & (1) & (2) & (3) & (4) & (5) & (6) & (7) \\
\hline $\begin{array}{l}\text { Monopoly [ }=1 \text { if single } \\
\text { installer in market] }\end{array}$ & $\begin{array}{c}0.008 \\
(0.528)\end{array}$ & $\begin{array}{l}-0.343 \\
(0.383)\end{array}$ & $\begin{array}{l}-0.652^{*} \\
(0.374)\end{array}$ & $\begin{array}{c}-0.917^{* *} \\
(0.377)\end{array}$ & $\begin{array}{c}-0.865^{\star *} \\
(0.397)\end{array}$ & $\begin{array}{c}-1.228^{* *} \\
(0.513)\end{array}$ & $\begin{array}{l}-1.547^{*} \\
(0.800)\end{array}$ \\
\hline Module Model FE & & $x$ & $x$ & $x$ & $x$ & $x$ & $x$ \\
\hline Installer FE & & & $x$ & $x$ & $x$ & $x$ & $x$ \\
\hline System Characteristics & & & & $x$ & $x$ & $x$ & $x$ \\
\hline House Characteristics & & & & & $x$ & $x$ & $x$ \\
\hline Demographic Controls & & & & & & $x$ & $x$ \\
\hline Other Controls & & & & & & & $x$ \\
\hline Year*Quarter FE & $x$ & $x$ & $x$ & $x$ & $x$ & $x$ & $x$ \\
\hline No. of Observations & 581 & 581 & 581 & 581 & 581 & 581 & 581 \\
\hline $\begin{array}{l}\text { Note: Installer FEs are do } \\
\text { characteristics include es } \\
\text { rating, CSI rating squarec } \\
\text { square footage, number } \\
\text { include median income, } \mathrm{p} \\
\text { Other controls include a c } \\
\text { (BuyAmerican), cumulativ } \\
\text { experience with TPOs, hc } \\
\text { over } 10 \mathrm{~kW} \text { were omitted } \\
10 \% \text { nominal discount rat } \\
* * * p<0.01 \text {. Standard err }\end{array}$ & $\begin{array}{l}\text { s for cor } \\
\text { d Y1 sol } \\
\text { CSI reba } \\
\text { rooms, r } \\
\text { tage of t } \\
\text { / equal tc } \\
\text { iber of in } \\
\text { density } \\
\text { Il as sys } \\
\text { sumed } f\end{array}$ & $\begin{array}{l}\text { actors th } \\
\text { output, a } \\
\text { adjustec } \\
\text { nber of b } \\
\text { populati } \\
\text { ne if the } \\
\text { allations } \\
\text { tract, an } \\
\text { ns with } \\
\text { the NPC }\end{array}$ & $\begin{array}{l}\text { t hold }>5 \% \\
\text { dummy if } \\
\text { for MACF } \\
\text { edrooms, } \\
\text { n with a b } \\
\text { installer is } \\
\text { within a tra } \\
\text { a dumm } \\
\text { PCs great } \\
\text { calculatio }\end{array}$ & $\begin{array}{l}\text { of market } \\
\text { he system } \\
S \text { and ITC. } \\
\text { nd built ye } \\
\text { chelor's de } \\
\text { vertically in } \\
\text { t at the tim } \\
\text { for system } \\
\text { r than } \$ 20 \\
\text { s. Asterisk }\end{array}$ & $\begin{array}{l}\text { lare in ou } \\
\text { as more t } \\
\text { louse cha } \\
\text { Demogr } \\
\text { ree, and } \\
\text { grated, a } \\
\text { of adopt } \\
\text { that are } \\
\text { W or less } \\
\text { denote * }\end{array}$ & $\begin{array}{l}\text { sample. } \\
\text { an } 1 \text { inve } \\
\text { acteristic } \\
\text { phic con } \\
\text { nedian hc } \\
\text { dummy fo } \\
\text { n, install } \\
\text { bastal. Sy } \\
\text { than } \$ 0.5\end{array}$ & $\begin{array}{l}\text { stem } \\
\text { r, CSI } \\
\text { iclude } \\
\text { s } \\
\text { e value. } \\
\text { RRA } \\
\\
\text { ms } \\
\text { V. A } \\
<0.05 .\end{array}$ \\
\hline
\end{tabular}


Table A-5. Main Instrumental Variable Regression Estimates of the Effect of "Monopoly Based on \# of TPO Installations" on Price

\begin{tabular}{|c|c|c|c|c|c|c|c|}
\hline & (1) & (2) & (3) & (4) & (5) & (6) & (7) \\
\hline $\begin{array}{l}\text { Monopoly [=1 if single TPO } \\
\text { installer in market] }\end{array}$ & $\begin{array}{c}0.007 \\
(0.406)\end{array}$ & $\begin{array}{l}-0.277 \\
(0.318)\end{array}$ & $\begin{array}{l}-0.538^{*} \\
(0.323)\end{array}$ & $\begin{array}{c}-0.765^{* *} \\
(0.335)\end{array}$ & $\begin{array}{c}-0.738^{* *} \\
(0.356)\end{array}$ & $\begin{array}{c}-0.919^{* *} \\
(0.395)\end{array}$ & $\begin{array}{r}-1.015^{* *} \\
(0.514)\end{array}$ \\
\hline Module Model FE & & $x$ & $x$ & $x$ & $x$ & $x$ & $x$ \\
\hline Installer FE & & & $x$ & $x$ & $x$ & $x$ & $x$ \\
\hline System Characteristics & & & & $x$ & $x$ & $x$ & $x$ \\
\hline House Characteristics & & & & & $x$ & $x$ & $x$ \\
\hline Demographic Controls & & & & & & $x$ & $x$ \\
\hline Other Controls & & & & & & & $x$ \\
\hline Year*Quarter FE & $x$ & $x$ & $x$ & $x$ & $x$ & $x$ & $x$ \\
\hline No. of Observations & 581 & 581 & 581 & 581 & 581 & 581 & 581 \\
\hline
\end{tabular}

Note: Installer FEs are dummies for contractors that hold $>5 \%$ of market share in our sample. System characteristics include estimated Y1 solar output, a dummy if the system has more than 1 inverter, CSI rating, CSI rating squared, and CSI rebate adjusted for MACRS and ITC. House characteristics include square footage, number of bathrooms, number of bedrooms, and built year. Demographic controls include median income, percentage of the population with a bachelor's degree, and median house value. Other controls include a dummy equal to one if the installer is vertically integrated, a dummy for ARRA (BuyAmerican), cumulative number of installations within a tract at the time of adoption, installer experience with TPOs, housing density by tract, and a dummy for systems that are coastal. Systems over $10 \mathrm{~kW}$ were omitted as well as systems with NPCs greater than $\$ 20 / \mathrm{kW}$ or less than $\$ 0.5 / \mathrm{kW}$. A $10 \%$ nominal discount rate is assumed for the NPC calculations. Asterisks denote ${ }^{*} p<0.10,{ }^{* *} p<0.05$, $* * * p<0.01$. Standard errors clustered by census tract. 
Table A-6. Estimates for Entire Set of Controls for Each Concentration Measure

\begin{tabular}{|c|c|c|c|c|c|c|c|c|}
\hline & (1) & (2) & (3) & (4) & (5) & (6) & (7) & (8) \\
\hline Concentration measure used: & $\begin{array}{l}\mathrm{HHI} \\
\text { (Total) }\end{array}$ & $\begin{array}{l}\mathrm{HHI} \\
\text { (TPO } \\
\text { Only) }\end{array}$ & $\begin{array}{c}\text { \# of } \\
\text { Installer } \\
\text { s (Total) }\end{array}$ & $\begin{array}{c}\text { \# of } \\
\text { Installer } \\
\text { s (TPO } \\
\text { Only) }\end{array}$ & $\begin{array}{c}\text { Monopol } \\
\text { y }[=1 \text { if } \\
\text { HHI } \\
(\text { Total) }> \\
0.25]\end{array}$ & $\begin{array}{c}\text { Monopol } \\
\text { y [=1 if } \\
\text { HHI } \\
\text { (TPO } \\
\text { Only) }> \\
0.25]\end{array}$ & $\begin{array}{l}\text { Monopol } \\
\text { y [=1 if } \\
\text { single } \\
\text { installer }]\end{array}$ & $\begin{array}{c}\text { Monopol } \\
\text { y [=1 if } \\
\text { single } \\
\text { TPO } \\
\text { installer }]\end{array}$ \\
\hline \multirow[t]{2}{*}{ Concentration } & $-1.062^{* *}$ & $1.104^{* *}$ & $0.076^{*}$ & $0.164^{*}$ & $-0.535^{\star *}$ & $-1.168^{*}$ & $-1.547^{*}$ & $-1.015^{* *}$ \\
\hline & $(0.495)$ & $(0.535)$ & $(0.040)$ & $(0.098)$ & $(0.252)$ & $(0.697)$ & $(0.800)$ & $(0.514)$ \\
\hline \multirow[t]{2}{*}{ Buy American (ARRA indicator) } & $\overline{-}^{-}$ & $\overline{-}^{-}$ & $-1.860^{* *}$ & $-1.229^{*}$ & $-1.990^{* * *}$ & $-1.305^{\star}$ & $-2.168^{\star * \star}$ & $-1.698^{* *}$ \\
\hline & $(0.688)$ & $(0.697)$ & $(0.672)$ & $(0.703)$ & $(0.647)$ & $(0.670)$ & $(0.826)$ & $(0.728)$ \\
\hline \multirow[t]{2}{*}{ Cumulative installations } & 0.006 & 0.006 & 0.001 & 0.003 & 0.002 & 0.005 & 0.011 & 0.006 \\
\hline & $(0.006)$ & $(0.006)$ & $(0.007)$ & $(0.007)$ & -0.006 & $(0.008)$ & $(0.008)$ & $(0.006)$ \\
\hline \multirow[t]{2}{*}{ Installer experience } & $-0.008^{* *}$ & $-0.008^{*}$ & $-0.007^{\star}$ & -0.005 & $-0.008^{* *}$ & -0.008 & $-0.008^{*}$ & $-0.009^{* *}$ \\
\hline & $(0.004)$ & $(0.004)$ & $(0.004)$ & $(0.004)$ & $(0.004)$ & $(0.005)$ & $(0.004)$ & $(0.004)$ \\
\hline \multirow[t]{2}{*}{$\begin{array}{l}\text { Integrated [=1 if vertically } \\
\text { integrated] }\end{array}$} & $-1.291^{*}$ & $-1.213^{*}$ & $-1.439^{\star *}$ & $-1.211^{*}$ & $-1.144^{*}$ & -1.595 & $-1.409^{\star \star}$ & $-1.157^{*}$ \\
\hline & $(0.659)$ & $(0.629)$ & $(0.694)$ & $(0.663)$ & $(0.636)$ & $(0.969)$ & $(0.672)$ & $(0.596)$ \\
\hline \multirow[t]{2}{*}{ Single-family house density } & 0.0003 & 0.0002 & 0.0003 & 0.0005 & 0.0001 & 0.0004 & 0.0005 & 0.0002 \\
\hline & $(0.0003)$ & $\begin{array}{c}(0.0003 \\
)\end{array}$ & $(0.0003)$ & $(0.0004)$ & $(0.0002)$ & $(0.0003)$ & $(0.0004)$ & $(0.0003)$ \\
\hline \multirow[t]{2}{*}{ Coastal [=1 if yes] } & 0.013 & -0.007 & 0.086 & 0.082 & 0.020 & 0.085 & -0.030 & -0.038 \\
\hline & $(0.104)$ & $(0.102)$ & $(0.144)$ & $(0.167)$ & $(0.104)$ & $(0.166)$ & $(0.104)$ & $(0.100)$ \\
\hline \multirow[t]{2}{*}{ Median income } & 0.0004 & 0.001 & 0.001 & -0.0003 & 0.001 & 0.001 & -0.0002 & 0.001 \\
\hline & $(0.001)$ & $(0.001)$ & $(0.002)$ & $(0.003)$ & $(0.001)$ & $(0.002)$ & $(0.002)$ & $(0.001)$ \\
\hline \multirow[t]{2}{*}{$\%$ with bachelor's degree } & $0.846^{\star \star *}$ & $0.600^{\star *}$ & $0.640^{\star *}$ & $0.569^{* *}$ & $0.744^{\star \star *}$ & $0.648^{\star *}$ & $1.079^{\star \star *}$ & $0.571^{* *}$ \\
\hline & $(0.295)$ & $(0.257)$ & $(0.257)$ & $(0.263)$ & $(0.271)$ & $(0.305)$ & $(0.402)$ & $(0.266)$ \\
\hline \multirow[t]{2}{*}{ Median house value } & $-0.001^{* *}$ & $0.001^{* *}$ & $-0.001^{* *}$ & $-0.001^{*}$ & $-0.001^{* *}$ & $-0.001^{*}$ & $-0.001^{*}$ & $-0.001^{*}$ \\
\hline & $(0.0003)$ & $\begin{array}{c}(0.0003 \\
)\end{array}$ & $(0.0004)$ & $(0.0004)$ & $(0.0003)$ & $(0.0004)$ & $(0.0003)$ & $(0.0004)$ \\
\hline \multirow[t]{2}{*}{ House size (sq. ft.) } & 0.0001 & 0.0001 & 0.0001 & 0.0001 & 0.0001 & 0.0001 & 0.0001 & 0.0001 \\
\hline & $(0.0001)$ & $\begin{array}{c}(0.0001 \\
)\end{array}$ & $(0.0001)$ & $(0.0001)$ & $(0.0001)$ & $(0.0001)$ & $(0.0001)$ & $(0.0001)$ \\
\hline \multirow[t]{2}{*}{ Number of Bathrooms } & 0.022 & 0.023 & 0.021 & -0.013 & 0.036 & -0.012 & 0.013 & 0.023 \\
\hline & $(0.052)$ & $(0.055)$ & $(0.055)$ & $(0.059)$ & $(0.053)$ & $(0.065)$ & $(0.059)$ & $(0.060)$ \\
\hline \multirow[t]{2}{*}{ Number of Bedrooms } & 0.051 & 0.008 & 0.047 & 0.026 & 0.059 & 0.060 & 0.060 & 0.003 \\
\hline & $(0.052)$ & $(0.055)$ & $(0.053)$ & $(0.057)$ & $(0.051)$ & $(0.060)$ & $(0.058)$ & $(0.058)$ \\
\hline \multirow[t]{2}{*}{ Built year } & -0.002 & -0.003 & -0.004 & -0.004 & -0.003 & -0.001 & -0.001 & -0.004 \\
\hline & $(0.003)$ & $(0.003)$ & $(0.003)$ & $(0.003)$ & $(0.002)$ & $(0.003)$ & $(0.003)$ & $(0.003)$ \\
\hline \multirow[t]{2}{*}{ Y1 Estimated Production } & $0.0002^{*}$ & 0.0001 & 0.0001 & 0.0001 & $0.0002^{* *}$ & $0.0002^{*}$ & $0.0002^{*}$ & 0.0001 \\
\hline & $(0.0001)$ & $\begin{array}{c}(0.0001 \\
)\end{array}$ & $(0.0001)$ & $(0.0001)$ & $(0.0001)$ & $(0.0001)$ & $(0.0001)$ & $(0.0001)$ \\
\hline \multirow[t]{2}{*}{ More than 1 inverter [ $=1$ if yes] } & 0.192 & 0.139 & 0.103 & 0.043 & 0.163 & 0.138 & 0.271 & 0.182 \\
\hline & $(0.187)$ & $(0.181)$ & $(0.208)$ & $(0.219)$ & $(0.184)$ & $(0.187)$ & $(0.208)$ & $(0.187)$ \\
\hline \multirow[t]{2}{*}{ CSI Rating } & $\begin{array}{c}- \\
0.548^{* * *}\end{array}$ & $0.395^{\star *}$ & -0.3 & -0.1 & $-0.468^{* * *}$ & $-0.423^{* *}$ & $-0.674^{* * *}$ & $-0.387^{* *}$ \\
\hline & $(0.179)$ & $(0.174)$ & $(0.177)$ & $(0.245)$ & $(0.167)$ & $(0.196)$ & $(0.229)$ & $(0.187)$ \\
\hline \multirow[t]{2}{*}{ CSI Rating Squared } & 0.010 & 0.0002 & -0.001 & -0.008 & -0.0001 & -0.006 & 0.019 & 0.003 \\
\hline & $(0.012)$ & $(0.011)$ & $(0.011)$ & $(0.014)$ & $(0.011)$ & $(0.014)$ & $(0.015)$ & $(0.012)$ \\
\hline
\end{tabular}




\begin{tabular}{|c|c|c|c|c|c|c|c|c|}
\hline & (1) & (2) & (3) & (4) & (5) & (6) & (7) & (8) \\
\hline Concentration measure used: & $\begin{array}{c}\mathrm{HHI} \\
\text { (Total) }\end{array}$ & $\begin{array}{l}\mathrm{HHI} \\
\text { (TPO } \\
\text { Only) }\end{array}$ & $\begin{array}{c}\text { \# of } \\
\text { Installer } \\
\text { s (Total) }\end{array}$ & $\begin{array}{c}\text { \# of } \\
\text { Installer } \\
\text { s (TPO } \\
\text { Only) }\end{array}$ & $\begin{array}{c}\text { Monopol } \\
\text { y }[=1 \text { if } \\
\text { HHI } \\
(\text { Total) }> \\
0.25]\end{array}$ & $\begin{array}{c}\text { Monopol } \\
\text { y [=1 if } \\
\text { HHI } \\
\text { (TPO } \\
\text { Only) > } \\
0.25]\end{array}$ & $\begin{array}{c}\text { Monopol } \\
\text { y }[=1 \text { if } \\
\text { single } \\
\text { installer }]\end{array}$ & $\begin{array}{c}\text { Monopol } \\
\text { y [=1 if } \\
\text { single } \\
\text { TPO } \\
\text { installer] }\end{array}$ \\
\hline \multirow{2}{*}{ CSI Rebate (adjusted) } & 1.306 & 0.046 & 0.741 & 0.265 & 0.901 & 0.124 & 1.244 & -0.427 \\
\hline & $(1.597)$ & $(1.564)$ & $(1.451)$ & $(1.525)$ & $(1.463)$ & $(1.617)$ & (2.059) & $(1.794)$ \\
\hline No. of Observations & 581 & 581 & 581 & 581 & 581 & 581 & 581 & 581 \\
\hline \multicolumn{9}{|c|}{$\begin{array}{l}\text { Note: Contractor FEs, Module Model FEs, and quarter by year time FEs are included in each regression. Contractor FEs are } \\
\text { dummies for contractors that hold }>5 \% \text { of market share in our sample. System characteristics include estimated Y1 solar output, a } \\
\text { dummy if the system has more than } 1 \text { inverter, CSI rating, CSI rating squared, and CSI rebate adjusted for MACRS and ITC. House } \\
\text { characteristics include square footage, number of bathrooms, number of bedrooms, and built year. Demographic controls include } \\
\text { median income, percentage of the population with a bachelor's degree, and median house value. Other controls include a dummy if } \\
\text { the installer is vertically integrated, a dummy for ARRA (BuyAmerican), cumulative number of installations within a tract at the time } \\
\text { of adoption, installer experience with TPOs, housing density by tract, and a dummy for systems that are coastal. Systems over } 10 \\
\mathrm{~kW} \text { were omitted as well as systems with NPCs greater than } \$ 20 / \mathrm{kW} \text { or less than } \$ 0.5 / \mathrm{kW} \text {. A } 10 \% \text { nominal discount rate is assumed } \\
\text { for the NPC calculations. Asterisks denote }{ }^{*} p<0.10,{ }^{* \star} p<0.05,{ }^{* * *} p<0.01 \text {. Standard errors clustered by census tract. }\end{array}$} \\
\hline
\end{tabular}


Table A-7. Sensitivity to Discount Rate Assumption

\begin{tabular}{|c|c|c|c|}
\hline & (1) & $(2)$ & (3) \\
\hline & $\begin{array}{l}5 \% \text { Nominal } \\
\text { Discount Rate }\end{array}$ & $\begin{array}{l}7 \% \text { Nominal } \\
\text { Discount Rate }\end{array}$ & $\begin{array}{l}12 \% \text { Nominal } \\
\text { Discount Rate }\end{array}$ \\
\hline \multirow[t]{2}{*}{ HHI (Total) } & $-2.172^{* *}$ & $-1.643^{* *}$ & $-0.773^{*}$ \\
\hline & $(1.009)$ & $(0.750)$ & $(0.396)$ \\
\hline \multirow[t]{2}{*}{ HHI (TPO Only) } & $-2.258^{* *}$ & $-1.709^{* *}$ & $-0.804^{*}$ \\
\hline & $(1.079)$ & $(0.806)$ & $(0.428)$ \\
\hline \multirow[t]{2}{*}{ \# of Installers (Total) } & $0.179^{*}$ & $0.135^{\star}$ & $0.064^{*}$ \\
\hline & $(0.098)$ & $(0.074)$ & $(0.038)$ \\
\hline \multirow[t]{2}{*}{ \# of Installers (TPO Only) } & $0.335^{*}$ & $0.254^{*}$ & 0.119 \\
\hline & $(0.196)$ & $(0.148)$ & $(0.077)$ \\
\hline \multirow[t]{2}{*}{ Monopoly [ $=1$ if $\mathrm{HHI}($ Total $)>0.25]$} & $-1.095^{* *}$ & $-0.829^{* *}$ & $-0.390^{*}$ \\
\hline & $(0.517)$ & $(0.384)$ & $(0.201)$ \\
\hline \multirow[t]{2}{*}{ Monopoly [ $=1$ if $\mathrm{HHI}($ TPO Only) $>0.25$ ] } & $-2.388^{*}$ & $-1.807^{*}$ & -0.851 \\
\hline & $(1.421)$ & $(1.064)$ & $(0.540)$ \\
\hline \multirow[t]{2}{*}{ Monopoly [=1 if single installer in market] } & $-3.166^{*}$ & $-2.395^{\star *}$ & $-1.127^{*}$ \\
\hline & $(1.626)$ & $(1.215)$ & $(0.631)$ \\
\hline \multirow[t]{2}{*}{ Monopoly [ $=1$ if single TPO installer in market] } & $-2.075^{\star *}$ & $-1.571^{* *}$ & $-0.740^{*}$ \\
\hline & $(1.036)$ & $(0.775)$ & $(0.409)$ \\
\hline
\end{tabular}

Note: There are 582 observations used in each regression. Installer FEs are dummies for contractors that hold $>5 \%$ of market share in our sample. System characteristics include estimated $Y 1$ solar output, a dummy if the system has more than 1 inverter, CSI rating, CSI rating squared, and CSI rebate adjusted for MACRS and ITC. House characteristics include square footage, number of bathrooms, number of bedrooms, and built year. Demographic controls include median income, percentage of the population with a bachelor's degree, and median house value. Other controls include a dummy equal to one if the installer is vertically integrated, a dummy for ARRA (BuyAmerican), cumulative number of installations within a tract at the time of adoption, installer experience with TPOs, housing density by tract, and a dummy for systems that are coastal. Systems over $10 \mathrm{~kW}$ were omitted as well as systems with NPCs greater than $\$ 20 / \mathrm{kW}$ or less than $\$ 0.5 / \mathrm{kW}$. A $10 \%$ nominal discount rate is assumed for the NPC calculations. Asterisks denote ${ }^{*} p<0.10,{ }^{* *} p<0.05,{ }^{* * *} p<0.01$. Standard errors clustered by census tract. 


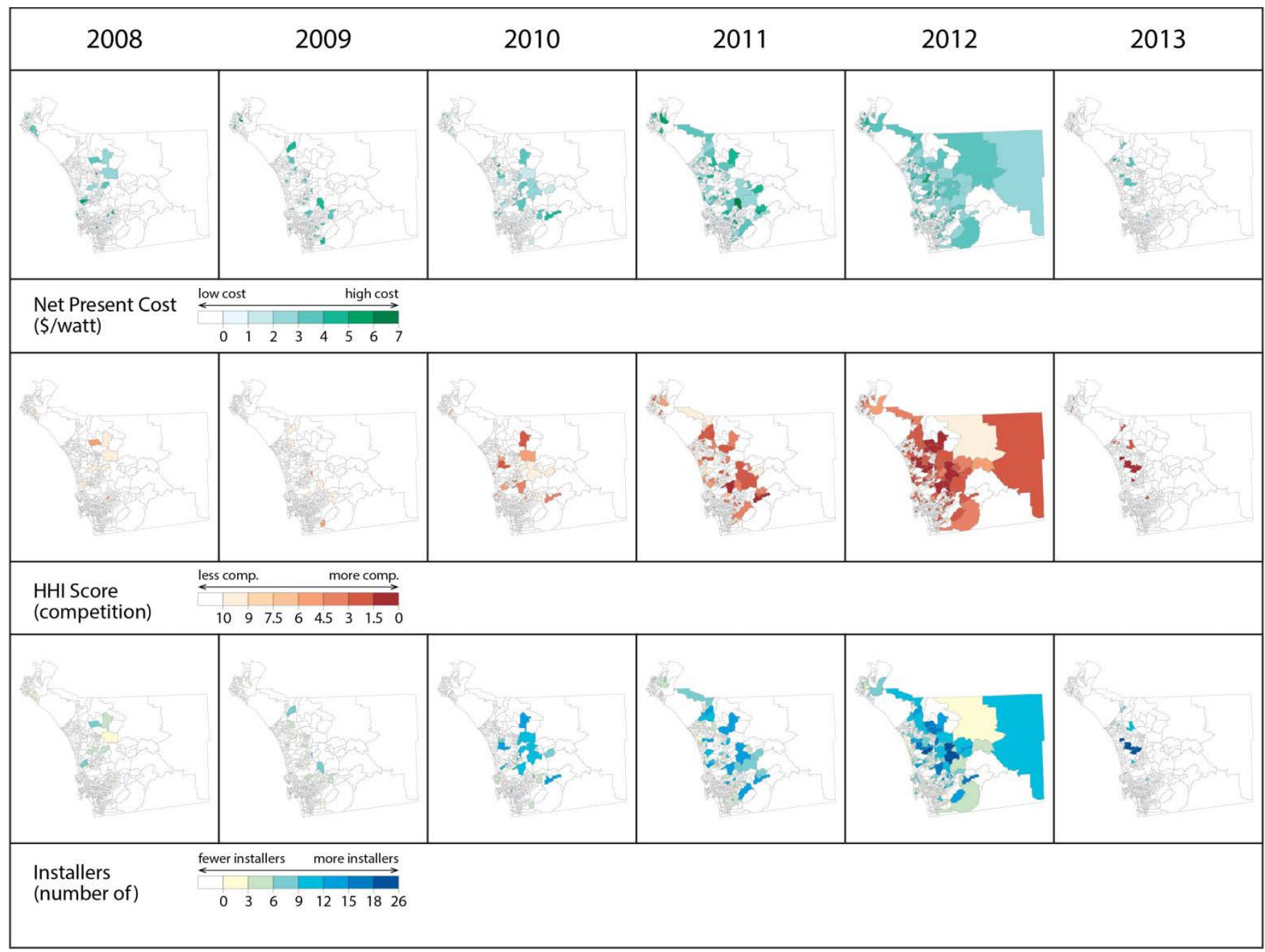

Figure A-1. Annual trends in contract net present cost $(\$ / W)$, $\mathrm{HHI}$ score, and number of installers active by tract in the region studied

The data visualized represent the data sample analyzed in this study and not the full set of market activity. 